\title{
A five-parameter temperature-corrected Murnaghan equation for P-V-T surfaces
}

Thomas G. Plymate

Missouri State University

James H. Stout

Follow this and additional works at: https://bearworks.missouristate.edu/articles-cnas

\section{Recommended Citation}

Plymate, Thomas G., and James H. Stout. "A five-parameter temperature-corrected Murnaghan equation for P-V-T surfaces." Journal of Geophysical Research: Solid Earth 94, no. B7 (1989): 9477-9483.

This article or document was made available through BearWorks, the institutional repository of Missouri State University. The work contained in it may be protected by copyright and require permission of the copyright holder for reuse or redistribution.

For more information, please contact BearWorks@library.missouristate.edu. 


\section{Journal of Geophysical Research: Solid Earth}

\section{RESEARCH ARTICLE \\ 10.1002/2014JB011029 \\ Thermal perturbations beneath the incipient Okavango Rift Zone, northwest Botswana}

Key Points:

- We estimated the Curie Point Depth, heat flow, and Moho depth beneath the ORZ

- Shallow CPD, elevated heat flow, and thin crust underlie the rift

- The presence of a thermal anomaly from hot fluids enhances strain localization

Correspondence to:

E. A. Atekwana,

estella.atekwana@okstate.edu

\section{Citation:}

Leseane, K., E. A. Atekwana, K. L. Mickus, M. G. Abdelsalam, E. M. Shemang, and E. A. Atekwana (2015), Thermal perturbations beneath the incipient Okavango Rift Zone, northwest

Botswana, J. Geophys. Res. Solid Earth, 120, 1210-1228, doi:10.1002/ 2014JB011029.

Received 7 FEB 2014 Accepted 2 JAN 2015 Accepted article online 8 JAN 2015 Published online 10 FEB 2015

\author{
Khumo Leseane', Estella A. Atekwana ${ }^{1}$, Kevin L. Mickus ${ }^{2}$, Mohamed G. Abdelsalam', \\ Elisha M. Shemang ${ }^{3}$, and Eliot A. Atekwana' \\ ${ }^{1}$ Boone Pickens School of Geology, Oklahoma State University, Stillwater, Oklahoma, USA, 'Department of Geography, \\ Geology and Planning, Missouri State University, Springfield, Missouri, USA, ${ }^{3}$ Department of Earth and Environmental \\ Science, Botswana International University of Science and Technology, Gaborone, Botswana
}

Abstract We used aeromagnetic and gravity data to investigate the thermal structure beneath the incipient Okavango Rift Zone (ORZ) in northwestern Botswana in order to understand its role in strain localization during rift initiation. We used three-dimensional (3-D) inversion of aeromagnetic data to estimate the Curie Point Depth (CPD) and heat flow under the rift and surrounding basement. We also used two-dimensional (2-D) power-density spectrum analysis of gravity data to estimate the Moho depth. Our results reveal shallow CPD values $(8-15 \mathrm{~km})$ and high heat flow $\left(60-90 \mathrm{~mW} \mathrm{~m}^{-2}\right)$ beneath a $\sim 60 \mathrm{~km}$ wide NE-trending zone coincident with major rift-related border faults and the boundary between Proterozoic orogenic belts. This is accompanied by thin crust $(<30 \mathrm{~km})$ in the northeastern and southwestern parts of the ORZ. Within the Precambrian basement areas, the CPD values are deeper (16-30 km) and the heat flow estimates are lower $\left(30-50 \mathrm{~mW} \mathrm{~m}^{-2}\right)$, corresponding to thicker crust $(\sim 40-50 \mathrm{~km})$. We interpret the thermal structure under the ORZ as due to upward migration of hot mantle fluids through the lithospheric column that utilized the presence of Precambrian lithospheric shear zones as conduits. These fluids weaken the crust, enhancing rift nucleation. Our interpretation is supported by 2-D forward modeling of gravity data suggesting the presence of a wedge of altered lithospheric mantle centered beneath the ORZ. If our interpretation is correct, it may result in a potential paradigm shift in which strain localization at continental rift initiation could be achieved through fluid-assisted lithospheric weakening without asthenospheric involvement.

\section{Introduction}

Numerical models presented to explain the initiation of continental rifts highlight the importance of magma ascending from an elevated asthenosphere in softening the lithosphere, hence enhancing lithospheric stretching [e.g., Buck, 2006; Bialas et al., 2010; Schmeling, 2010]. Buck [2006] suggested that continuous intrusion of dikes thermally weakens the lithosphere, therefore reducing the amount of driving force needed to nucleate rifting. In this model, extensional strain is localized and maintained through magma intrusions. Such magma-assisted rifting models have been validated through geophysical observations in the more developed segments of the East African Rift System (EARS) such as the Afar Depression and the Main Ethiopian Rift (Figure 1) [Ebinger and Casey, 2001; Ebinger, 2005; Kendall et al., 2005]. Nonetheless, the role of magma in the initiation of rifting within nascent segments of the EARS such as the southwestern branch (Figure 1) where magmatism has yet to breach the surface has not been fully validated.

Our understanding of the initiation of extension within amagmatic and magma-poor rift zones is limited due to the paucity of geophysical observations of the crust and upper mantle underlying these structures. Within amagmatic rift segments of the EARS, surface magmatism is often missing despite the presence of diagnostic rift features such as well-developed border faults and deep asymmetrical grabens [e.g., Chorowicz, 2005]. These observations call into question that magma injected into the lithosphere from an elevated asthenosphere might be the only process responsible for rift initiation. Thus, there is a need to consider alternative geodynamic processes to explain rift initiation within amagmatic rift segments.

Hence, the thermal structure beneath incipient rift zones is an important parameter that could be used to understand and constrain mechanisms responsible for strain localization during the onset of rifting. Heat flow measurements obtained from boreholes and deep mines provide direct assessment of the thermal structure of the lithosphere [e.g., Pollack et al., 1993]. The sparse distribution of boreholes and their limited depth 


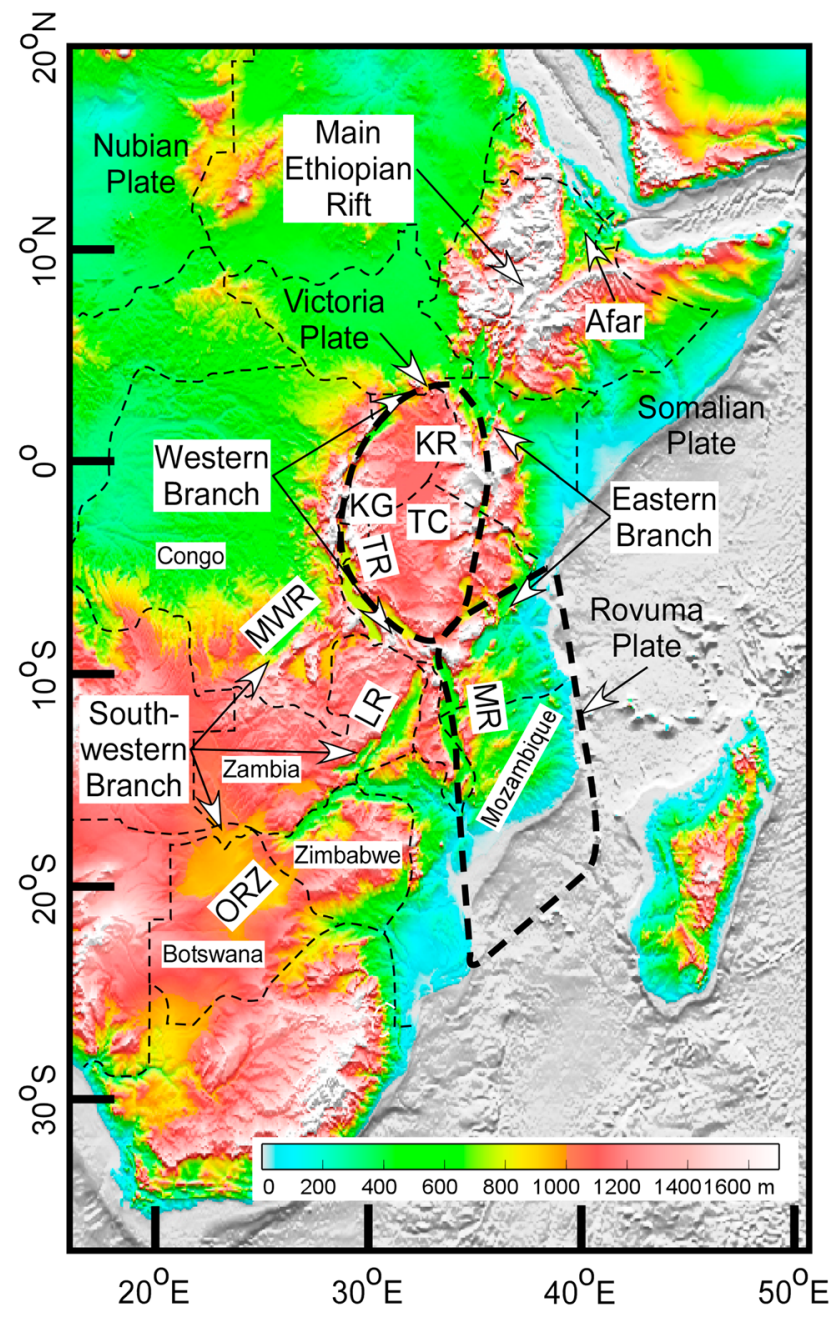

Figure 1. Digital Elevation Model (DEM) extracted from the Global 30 Arc Second Elevation Data (GTOPO30, $1 \mathrm{~km}$ spatial resolution) showing the different parts of the southwestern branch of the East African Rift System. $\mathrm{KR}=$ Kenya rift; $\mathrm{KG}=$ Kivu rift; $\mathrm{TR}=$ Tanganyika rift; $\mathrm{TC}=$ Tanzanian craton; $M W R=$ Mweru rift; $L R=$ Luangwa rift; $M R=$ Malawi rift; $O R Z=$ Okavango Rift Zone.

of metasomatized lithospheric mantle resides beneath the ORZ. This suggests a major role of mantle fluids in strain localization during the initiation of ORZ.

\section{The Okavango Rift Zone}

The EARS is a classic example of a continental rift system. The EARS is divided into the eastern, western, and southwestern branches (Figure 1). Current $\sim$ E-W extension across the EARS (Figure 1) is largely due to 5-6 mm/yr of Nubian-Somalian plate divergence in the north with a general decrease in extension rate from north to south accommodated by Victoria, Rovuma, and Lwandle block rotation reaching less than $1 \mathrm{~mm} / \mathrm{yr}$ in the southernmost extension of the EARS [e.g., Calais et al., 2006; Horner-Johnson et al., 2007; Stamps et al., 2008; Saria et al., 2014]. Most of Africa's recorded seismicity is concentrated along the EARS with larger magnitude and deeper seismicity concentrated where lithospheric estimates are thickest within the western branch [Yang and Chen, 2010; Craig et al., 2010]. The age of rift initiation varies in different parts of the EARS. However, a recent study suggests that rift initiation was probably coeval at $25 \mathrm{Ma}$ within the eastern and western branches [e.g., Roberts et al., 2012]. The southwestern branch extends southwestward for $\sim 1700 \mathrm{~km}$ from Lake Tanganyika and Lake Malawi as a $\sim 250 \mathrm{~km}$ wide zone of extensional structures [Reeves, 1972; Scholz et al., 1976; Ballard et al., 1987; Modisi et al., 2000; Kinabo et al., 2007, 2008; Mosley-Bufford et al., 2012$].$ 

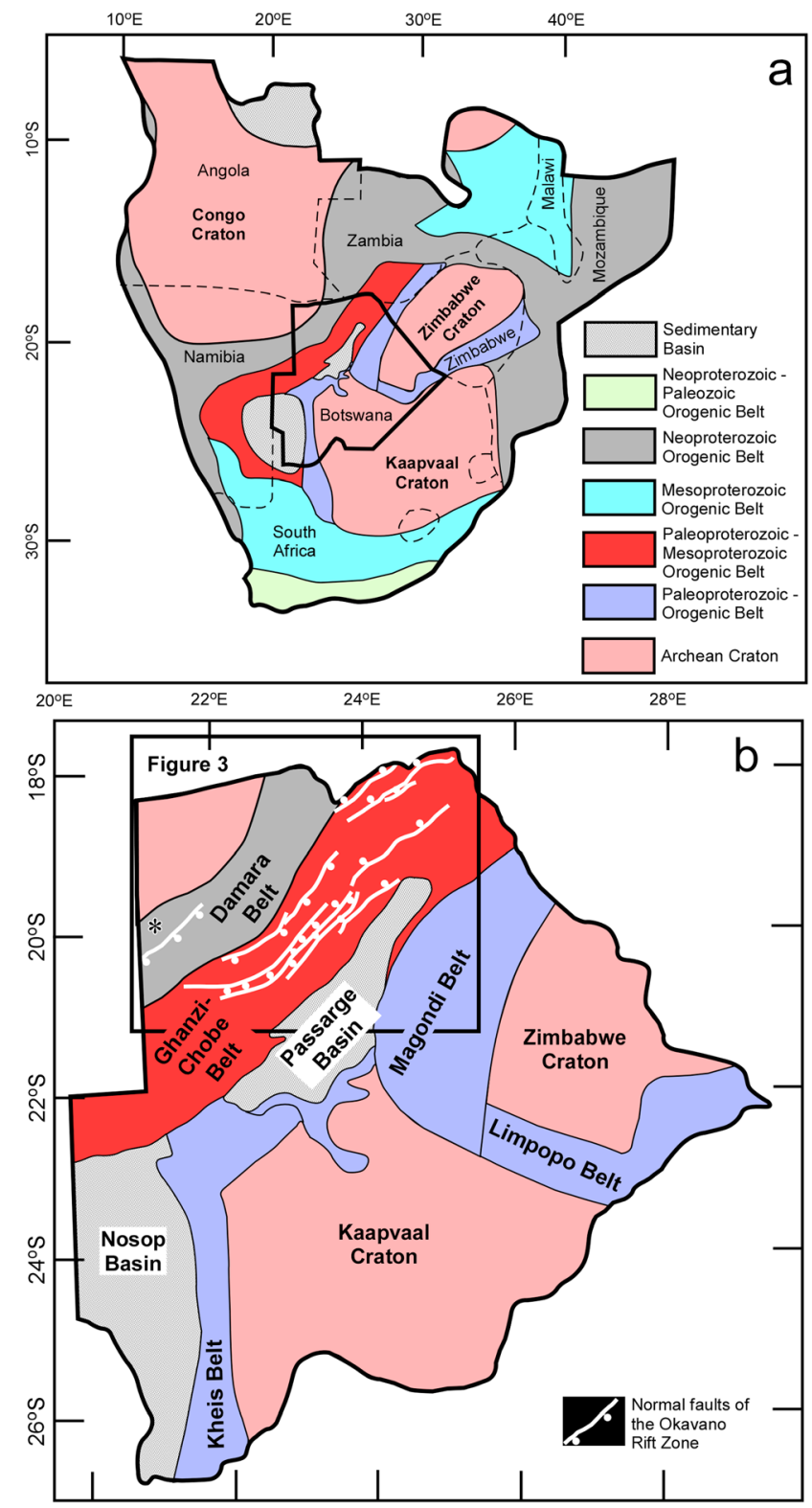

Figure 2. Precambrian tectonic map of (a) southern Africa and (b) Botswana outlining the spatial extent of Archean cratons and Proterozoic orogenic belts. White lines represent the fault system of the Okavango Rift Zone. Modified after Singletary et al. [2003] and Begg et al. [2009].
It consists of a series of $\sim 100 \mathrm{~km}$ long and $40-80 \mathrm{~km}$ wide Quaternary rift basins. The most prominent of these rift basins is the Mweru rift which extends southwest from the Tanganyika rift and the Luangwa rift which extends southwest from the Malawi rift (Figure 1). The ORZ represents the southwesternmost extensional structures along the trend of the southwestern branch of the EARS (Figure 1). The ORZ is developing within Precambrian orogenic belts, namely, the NE trending Mesoproterozoic-Neoproterozoic Ghanzi-Chobe belt in the southeast and the Neoproterozoic-Early Paleozoic Damara belt to the northwest (Figures 2 and 3b). These two belts, together with the Paleoproterozoic Magondi and Kheis belts, are sandwiched between the Archean Congo craton to the northwest and the Kaapvaal and Zimbabwe cratons to the southeast (Figure 2). The Damara-Ghanzi-Chobe orogenic belts are characterized by NE-trending folds and faults [Modisi et al., 2000; Kinabo et al., 2008; Mosley-Bufford et al., 2012]. This Precambrian basement is partially covered by unconsolidated Quaternary sediments of the Kalahari alluvium and Holocene lacustrine sediments within paleo-lakes [Ringrose et al., 2005].

The northeastern part of the ORZ is underlain by the Karoo sedimentary and volcanic rocks that rest unconformably on the Precambrian crystalline rocks (Figure 3b) [Key and Ayres, 2000]. In northwestern

Botswana, the Karoo sedimentary rocks are represented by Triassic age Lebung group which is made up dominantly of sandstones and siltstones [Key and Ayres, 2000]. The thickness of this group is not known, but we expect it to be less than $2000 \mathrm{~m}$ since it represents only one of four groups forming the entire Karoo sedimentary section which collectively have a maximum thickness of $2000 \mathrm{~m}$. The Karoo volcanic rocks are represented by the Jurassic age Karoo basalts which have an average thickness of $1000 \mathrm{~m}$ [Key and Ayres, 2000].

From a compilation of previous work, surface geology, interpretation of aeromagnetic data, and borehole data Key and Ayres [2000] divided the Ghanzi-Chobe belt into five formations (Figure 3b). These include the Mesoproterozoic age Kgwebe (metamorphosed rhyolites, basalts, and volcaniclastic metasedimentary rocks) and Goha formation (metamorphosed rhyolites and volcaniclastic metasedimentary rocks with minor cherts) as well as the Neoproterozoic age Ngwako Pan (metamorphosed arkosic sandstones), D'kar (metamorphosed sandstones, siltstones, and mudstones), and Chinamba Hills formation (metamorphosed 

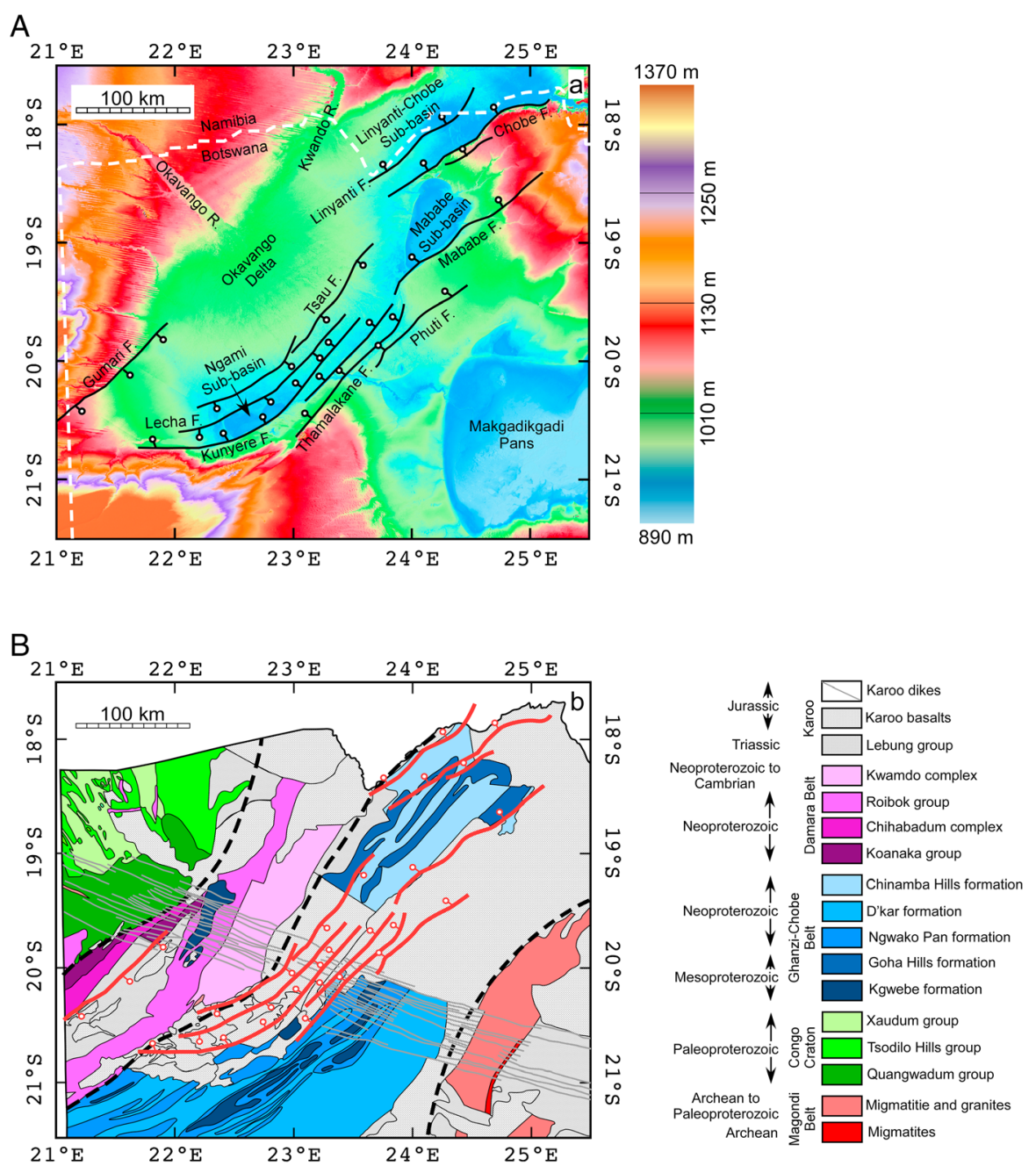

Figure 3. (a) Shuttle Radar Topographic Mission (SRTM) Digital Elevation Model (DEM) of the Okavango Rift Zone showing the geomorphological features of the study area including the different subbasins and fault systems of the ORZ. (b) Geological map covering the same area as Figure 3a showing the surface and subsurface Precambrian-Paleozoic geology below the Kalahari alluvium, Holocene lacustrine sediments, and rift sediment fill. Modified after Key and Ayres [2000].

sandstones and siltstones). Key and Ayres [2000] also divided the Damara belt into four units (Figure 3b). These include the Neoproterozoic age Koanaka (granitic gneisses and marbles), Chihabadum (undifferentiated igneous and metaigneous rocks), and Roibok formation (granitic gneisses and amphibolite schists) as well as the Neoproterozoic-Cambrian age Kwamdo complex (granitic gneisses, granites, granites, amphibolite gneisses, migmatities, and metadolerite). Additionally, Key and Ayres [2000] divided the part of the Paleoproterozoic age Congo craton that extends into northwestern Botswana into the Quangwadum (granitic gneisses), Tsodilo (dominantly quartzites and quartz-mica schists), and Xaudum group (siliciclastic and carbonate sedimentary rocks and ironstones).

In the Okavango, rifting has diverted several of Africa's major river systems (Zambezi, Kwando, and tributaries), altering surface drainage and thereby proving a dramatic example of how rifting affects surface processes [Ringrose et al., 2005]. Additionally, the ORZ hosts the Okavango "Delta" (Figure 3a) the largest inland (continental) alluvial fan in the world, with an approximate area of $22,000 \mathrm{~km}^{2}$, supporting a very delicate ecosystem and a freshwater reservoir [e.g., McCarthy et al., 1997; McCarthy and Ellery, 1998; Wolski and Savenije, 2006]. Within the Okavango Delta, neotectonic activity has strongly influenced the drainage and geomorphology of the alluvial fan system. 


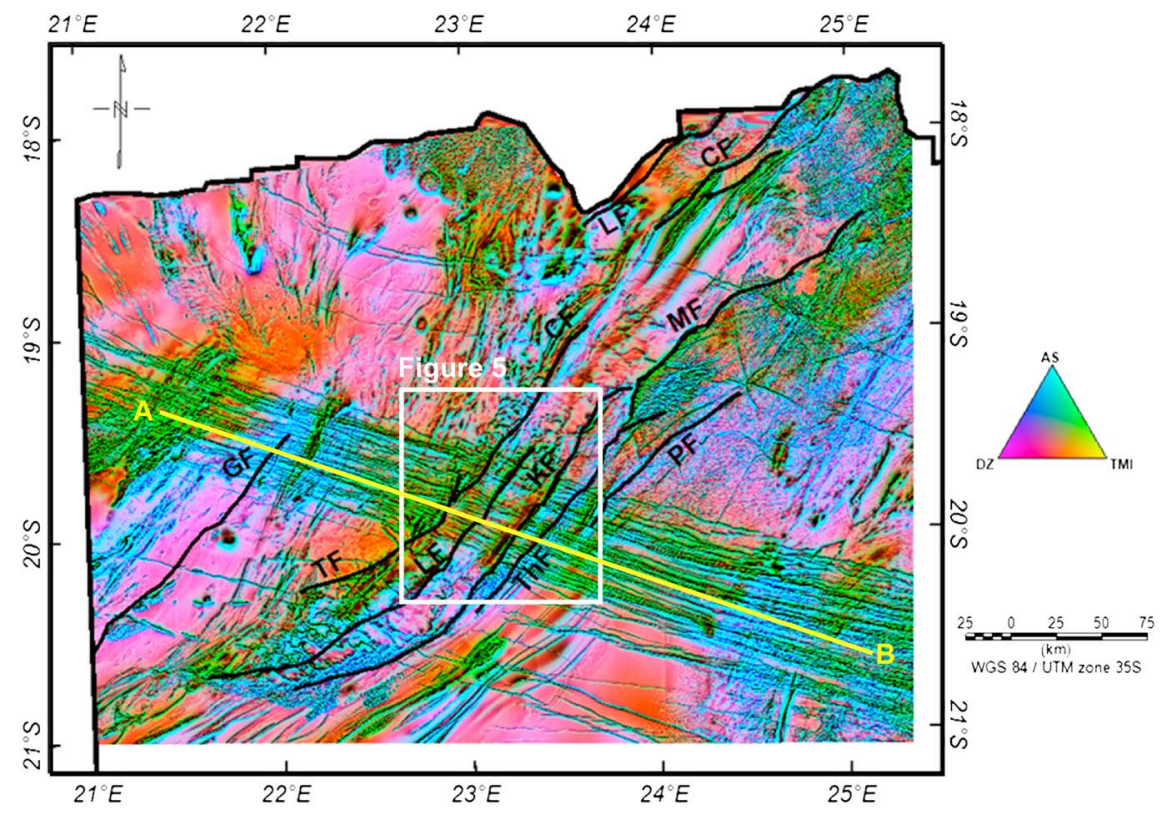

Figure 4. Ternary magnetic image of the Okavango Rift Zone. The image was generated by the combination of the first vertical derivative (DZ), total magnetic intensity (TMI), and analytical signal (AS) in Red-Green-Blue color space. The NE trending magnetic anomalies are the result of regional Proterozoic fabric within the Damara-Ghanzi-Chobe belt. The NW trending magnetic anomalies represent the Okavango Dike Swarm. The white box represents the location of the $1^{\circ} \times 1^{\circ}$ block used for the three-dimensional inversion model shown in Figures 5 and 6 . The yellow line $A-B$ shows the trace of the cross section presented in Figure 12. LF $=$ Linyanti fault; $G F=$ Gumare fault; $C F=C h o b e$ fault; $M F=$ Mababe fault; $M B=$ Magondi belt; TF = Tsau fault; $L F=$ Lecha fault; $K F=$ Kunyere fault; ThF = Thamalakane fault; $P F=$ Phuti fault.

The ORZ contains three areas of maximum sedimentary deposition including the Ngami, Mababe, and Linyanti-Chobe subbasins (Figure 3a). The Linyanti-Chobe subbasin is found in the northeastern part of the ORZ and is bounded by the Chobe and Linyanti faults. The Mababe subbasin is bounded by the Chobe fault to the northwest and the Mababe fault to the southeast. The Ngami subbasin forms the southwestern terminus of the ORZ and is bounded by the Kunyere to the northwest and Thamalakane faults to the southeast [Modisi et al., 2000; Kinabo et al., 2008; Mosley-Bufford et al., 2012]. These subbasins are filled with Quaternary lacustrine and fluvio-deltaic sediments. Previous studies used Euler deconvolution solutions of aeromagnetic data to estimate sediment thickness within the Ngami and Mababe subbasins and found it to be between 400 and 800 m, respectively [Kinabo et al., 2007; Shemang and Molwalefhe, 2009].

The ORZ has been the focus of surface and subsurface geologic and geophysical investigations aimed at determining its geometry and deciphering the nature and kinematics of the associated faults. Passive seismic investigations have focused on resolving the focal mechanisms associated with rift-related faulting [Reeves, 1972; Scholz et al., 1976]. Scholz et al. [1976] determined that focal mechanisms of the NE trending faults of the ORZ indicate normal faulting within a $150 \mathrm{~km}$ wide zone of extension occurring between the Gumare and the Thamalakane faults (Figure 3a). Modisi et al. [2000] used filtered aeromagnetic data and cross-cutting relationships between the rift faults and the Okavango Dike Swarm to postulate that the faults within the ORZ are normal faults that exploited preexisting zones of weaknesses in the Precambrian basement (Figure 4). Kinabo et al. [2008] integrated Shuttle Radar Topography Mission (SRTM) Digital Elevation Models (DEM) and aeromagnetic data to reveal the fault development pattern and suggested that although the width of the ORZ is approximately $150 \mathrm{~km}$, most of the subsidence and strain localization is occurring within a $\sim 60 \mathrm{~km}$ wide graben along the southeastern margin of the rift between the Tsau and Thamalakane faults (Figure 3a).

Results from shallow MT along a profile from the Gumare fault to the Kunyere fault and 2-D inversion of direct current electrical resistivity measurements across the Ngami subbasin were used to show that the ORZ is an 
asymmetrical half-graben with the main border fault occurring along the southeastern side of the rift [Mosley-Bufford et al., 2012]. Mosley-Bufford et al. [2012] proposed that the presence of fluids acts as a lubricant promoting microseismicity along the developing normal faults.

Results from MT surveys along regional profiles carried out as part of the Southern African Magnetotelluric Experiment (SAMTEX) provided the first lithospheric-scale electrical imaging beneath the region. The SAMTEX experiment results suggest variations in the thickness of the lithosphere from the cratons to the orogenic belts, with thicker lithospheric keels $(\sim 180-250 \mathrm{~km})$ beneath the Congo and Kaapvaal cratons compared to a thinner $(\sim 160 \mathrm{~km})$ lithosphere beneath the Damara-Ghanzi-Chobe orogenic belts [Muller et al., 2009; Miensopust et al., 2011; Khoza et al., 2013].

The age of the onset of rifting in the ORZ is not known. However, studies using paleo-environmental reconstruction from sediments and surface expression of features such as sand dunes and diversion of major drainage patterns suggest that rifting started in the Holocene. Moore and Larkin [2001] used the impoundment of the Okavango River (Figure 3a) and change in drainage patterns and displacement along the NE trending faults of the ORZ to suggest that rifting initiated between $\sim 120 \mathrm{ka}$ and $\sim 40 \mathrm{ka}$. These results are supported by evidence from sediments collected in the Mababe subbasin whereby a shift in hydrology and sedimentation is inferred from grain size distribution, magnetic susceptibility, and inorganic carbon, organic carbon, and metal concentration data [Gamrod, 2009].

\section{Methodology}

\subsection{Curie Point Depth Analysis}

The method to use magnetic data to estimate the Curie Point Depth (CPD) (the depth at which materials of the crust and uppermost mantle reach their Curie point (CP)) was first suggested by Bhattacharyya [1964] and subsequently improved by Spector and Grant [1970], Bhattacharyya and Leu [1975], and Tanaka et al. [1999]. The CP, the temperature at which materials lose their ability to be permanently magnetized, varies for different minerals but typically ranges between 550 and $580^{\circ} \mathrm{C}$ for the upper crust. The depth to the base of the magnetized layer is therefore directly related to the $\mathrm{CP}$, and variations in this depth can be correlated to either heat flow and geothermal gradient or thermal properties of the lithosphere [Aboud et al., 2011; Arnaiz-Rodrigues and Orihuela, 2013]. The CPD is largely influenced by the regional tectonic setting such as old stable cratons versus more active tectonic regimes including subduction and rift zones [Arnaiz-Rodrigues and Orihuela, 2013]. The CPDs can be used as a proxy for imaging the thermal structure of the lithosphere [Ross et al., 2006].

The depth and geometry of the base of the magnetized crust beneath the ORZ and the surrounding Precambrian basement was evaluated using the 3-D inversion of the residual aeromagnetic anomaly data to estimate the CPD. Inversion models were generated using the MAG3D modeling software developed by the University of British Columbia, based on the algorithm of Li and Oldenburg [1996]. Traditionally, the CPD is determined using 2-D spectral methods [Spector and Grant, 1970; Byerly and Stolt, 1977; Shuey et al., 1977; Bhattacharyya and Leu, 1975; Okubo et al., 1985; Tanaka et al., 1999; Ross et al., 2006; Hussein et al., 2013; Arnaiz-Rodrigues and Orihuela, 2013]. This method has been used successfully to determine the regional CPD values over large study areas [e.g., Blakely, 1988; Ross et al., 2006; Hussein et al., 2013; Arnaiz-Rodrigues and Orihuela, 2013]. The major drawback associated with the 2-D spectral method is the incorporation of local horizontal variations $(<15 \mathrm{~km})$ in the CPD values. Hence, we chose to use the 3-D inversion method instead of the 2-D spectral method to overcome limitations in delineating smaller-scale variations in the CPDs as suggested in Hussein et al. [2013].

The aeromagnetic data (Figure 4) used in this study were acquired in 1996 by the Geological Survey of Botswana at a flight altitude of $\sim 80 \mathrm{~m}$ along N-S lines with line spacing of $250 \mathrm{~m}$ and E-W tie lines with $1.25 \mathrm{~km}$ separation. The data were provided as a uniform grid with a cell size of $62.5 \mathrm{~m}$ using a minimum curvature technique. The 1995 epoch International Geomagnetic Reference Field (IGRF) was removed from the data. This is essential in determining the CPD as it represents the noncrustal magnetic field [Ravat et al., 2007]. However, prior to the 2000 epoch, a spherical harmonic degree 10 main field model was used for the IGRF, and such a removal left behind some portion of the main magnetic field in the resulting crustal magnetic anomaly [Ravat et al., 2007]. The remaining portion of the main magnetic field has a long wavelength 


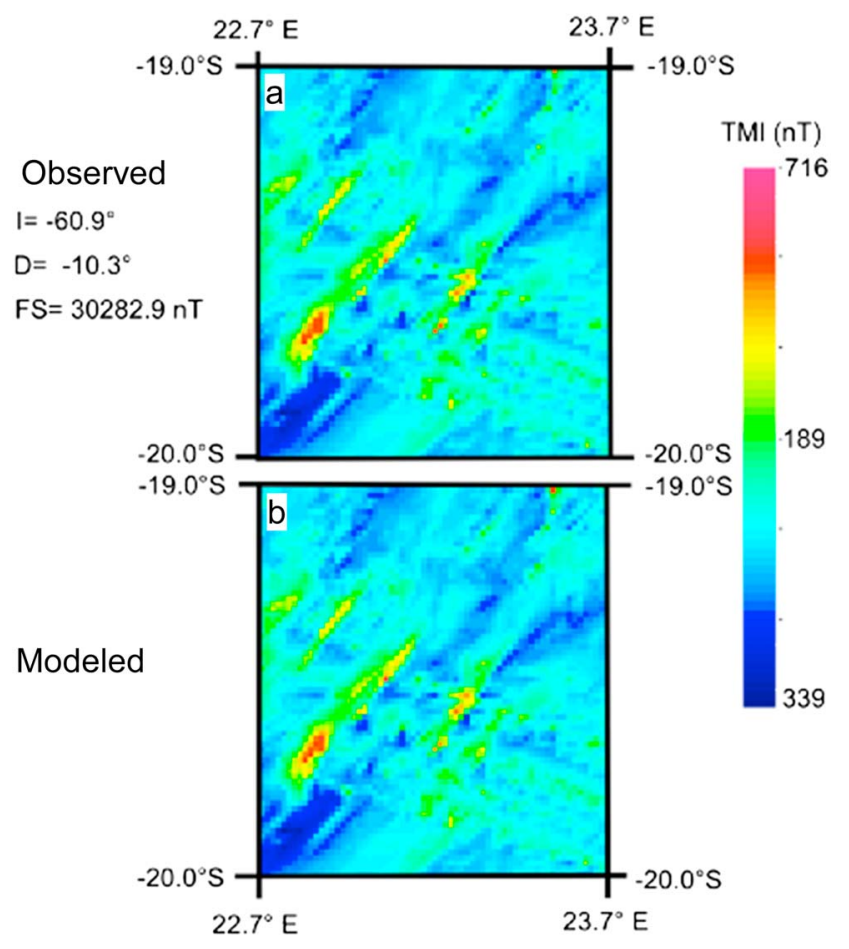

Figure 5. (a) Observed and (b) calculated magnetic anomalies of the threedimensional magnetic inversion model of the $1^{\circ} \times 1^{\circ}$ block shown in Figure 4 . $\mathrm{I}=$ inclination; $\mathrm{D}=$ declination; $\mathrm{FS}=$ total field strength.
( $>500 \mathrm{~km}$ ) which given the size of our blocks $(120 \times 120 \mathrm{~km})$ would not affect the CPD calculations [Ravat et al., 2007].

To reliably resolve the top and base of magnetic anomaly sources without independent constraints such as seismic data or borehole information, different inversion parameters (e.g., weighting of the data, data errors, choice of objective function, starting model, and size of model mesh) were systematically adjusted so that the inversion model best agrees with the known geology of the region (Figure $3 \mathrm{~b}$ ) following the methods of Hussein et al. [2013]. Since magnetic data have no inherent depth resolution, this means that when inverting for a magnetic susceptibility distribution, the distributions tend to concentrate near the surface. To remedy this problem, Li and Oldenburg [1996] used depth weighting of the data by multiplying the sensitivity matrix by

a function that varies with depth so that the recovered model will be concentrated near the surface. Various weighting factors were applied, and although values between 2 and 4 produced similar results, we found that a factor of 3, as suggested by Li and Oldenburg [1996], produced models that best agree with the known geology.

The region covered by the aeromagnetic data of the ORZ and surroundings (Figure 4) is discretized into $1^{\circ} \times 1^{\circ}$ $(\sim 120 \times 120 \mathrm{~km})$ subregions, and the causative magnetization directions for the center of each subregion are used in the modeling. For each model, the cell mesh size is $900 \mathrm{~m}$ for each subblock and is increased to $1800 \mathrm{~m}$ for regions outside the subblock. Cell blocks are needed outside the region of interest due to anomalies that are close to the boundary of the subblock or if there are anomalies outside the subblock which cannot be easily removed [Li and Oldenburg, 1996]. A range in magnetic susceptibility values based on the magnetic anisotropy results of Aubourg et al. [2008] for the Okavango Dike Swarm (0.0-0.03 SI) were used (due to the dominance of dikes in the basement) in order to determine which bodies produced by the inversion process were similar in each inversion. To test the resolution of our models, we inverted the data using at least five different starting models, where the initial magnetic susceptibility values were varied. For each model we ran a minimum of five inversions and determined the depth to the bottom of the magnetic sources in the subregion and compiled this to determine the CPD of the study area. Although each of the inversions produced similar final models, we have chosen the model that best agrees with the known geology.

Figure 5 shows an example of the observed and calculated magnetic anomalies from a $1^{\circ} \times 1^{\circ}$ subregion (shown in Figure 4) from our 3-D inversion. Figure 6a shows the 3-D inversion model cube of the aeromagnetic data used in the calculation of the CPD for the same subset together with 2-D E-W slices (labeled $\mathrm{i}-\mathrm{v}$ ) illustrating the 3-D inversion of the aeromagnetic data used for the calculation of CPD. The CPD was chosen as the base of high-amplitude magnetic susceptibility anomaly sources (Figure $6 a$ ). Figure $6 \mathrm{~b}$ is a NW-SE cross section (the cross section baseline is shown in Figure 4) showing the CPD under the ORZ and surroundings as obtained from the 3-D inversion of the aeromagnetic data.

\subsection{Heat Flow Estimates From CPD}

The CPD values obtained from the 3-D inversion of aeromagnetic data can be used to estimate regional heat flow [Tanaka et al., 1999; Bouligand et al., 2009; Hussein et al., 2013]. There are many variables that control 

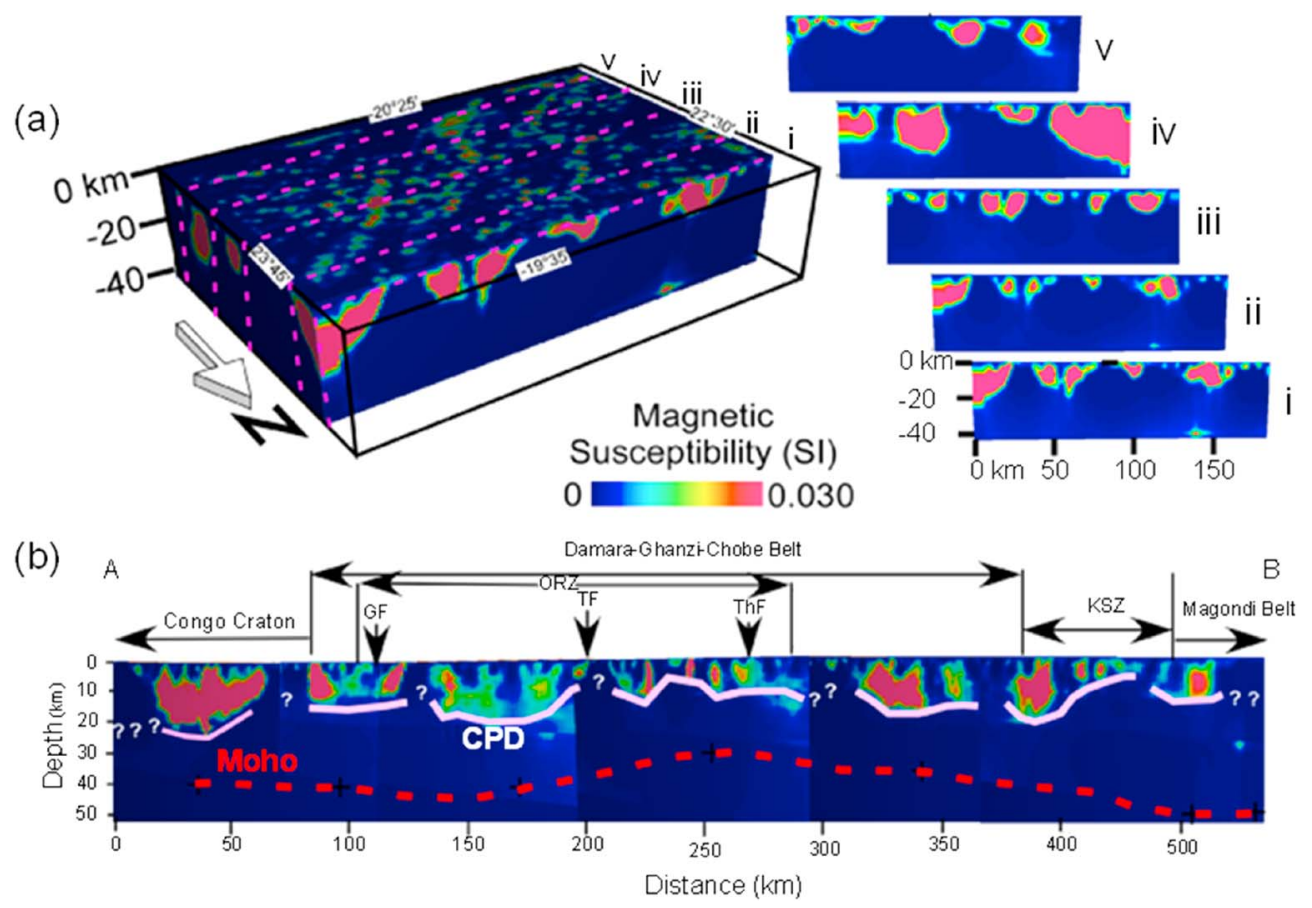

Figure 6. (a) The $1^{\circ} \times 1^{\circ}$ block (of the area shown on Figure 5) with E-W depth slices (labeled i, ii, iii, iv, and v) illustrating the three-dimensional (3-D) inversion of the aeromagnetic data used for the calculation of Curie Point Depth. (b) The 3-D inversion of magnetic data for susceptibility displayed in a cross section along a NW-SE profile showing the distribution of magnetization beneath the Okavango Rift Zone and surrounding terrains. GF = Gumare fault; TF = Tsau fault; $\mathrm{ThF}=$ Thamalakane fault; KSZ = Kalahari Suture Zone. The pink and red lines are the approximate bases of magnetization and Moho depth, respectively.

regional heat flow including Curie temperature of magnetic minerals, the heat flow equation used in the calculation, and the thermal conductivity of the underlying lithologies. The most common magnetic mineral causing the regional magnetic anomalies is magnetite that has a Curie temperature of $580^{\circ} \mathrm{C}[$ Haggerty, 1978]. The Curie temperature can be as high as $600^{\circ} \mathrm{C}$ if the amount of titanium is increased to the level of forming titanomagnetite [Stacey and Banerjee, 1974; Frost and Shive, 1986]. The Curie temperature decreases to below $580^{\circ} \mathrm{C}$ if the magnetic minerals are forms of iron sulfides (e.g., $325^{\circ} \mathrm{C}$ for pyrrhotite) [Hunt et al., 1995]. An additional variable is the thermal conductivity which ranges between $1.3-3.3 \mathrm{~W} \mathrm{~m}^{-1} \mathrm{~K}^{-1}$ for granites and 2.5-5.0 $\mathrm{W} \mathrm{m}^{-1} \mathrm{~K}^{-1}$ for metamorphic rocks [Lillie, 1999]. The dominant lithologies underlying the ORZ include Precambrian gneisses, volcano-sedimentary rocks, and granitoids [Modie, 2000] (Figure 3b). Since we are only interested in a first-order estimation of the regional heat flow, we used the one-dimensional (1-D) conductive heat flow equation where the temperature gradient is constant. Heat-producing radiogenic isotopes within the Precambrian basement can contribute to the calculated absolute heat flow values. This contribution is expected to be uniform and will not result in sharp variation in the heat flow values because of close similarities in lithological units of the region (Figure 3b).

The 1-D Fourier's Law conductive heat flow equation that assumes constant temperature gradient was used to calculate the heat flow values under the ORZ and surroundings. The Fourier's Law is given by

$$
q=k(\mathrm{~d} T / \mathrm{d} z)
$$

where $q$ is heat flux, $k$ is thermal conductivity, $T$ is temperature, $z$ is depth, and $\mathrm{d} T / \mathrm{d} z$ is temperature gradient.

Tanaka et al. [1999] showed that the Curie temperature, C, can be defined as

$$
C=(\mathrm{d} T / \mathrm{d} z) D
$$

where $D$ is the CPD. 


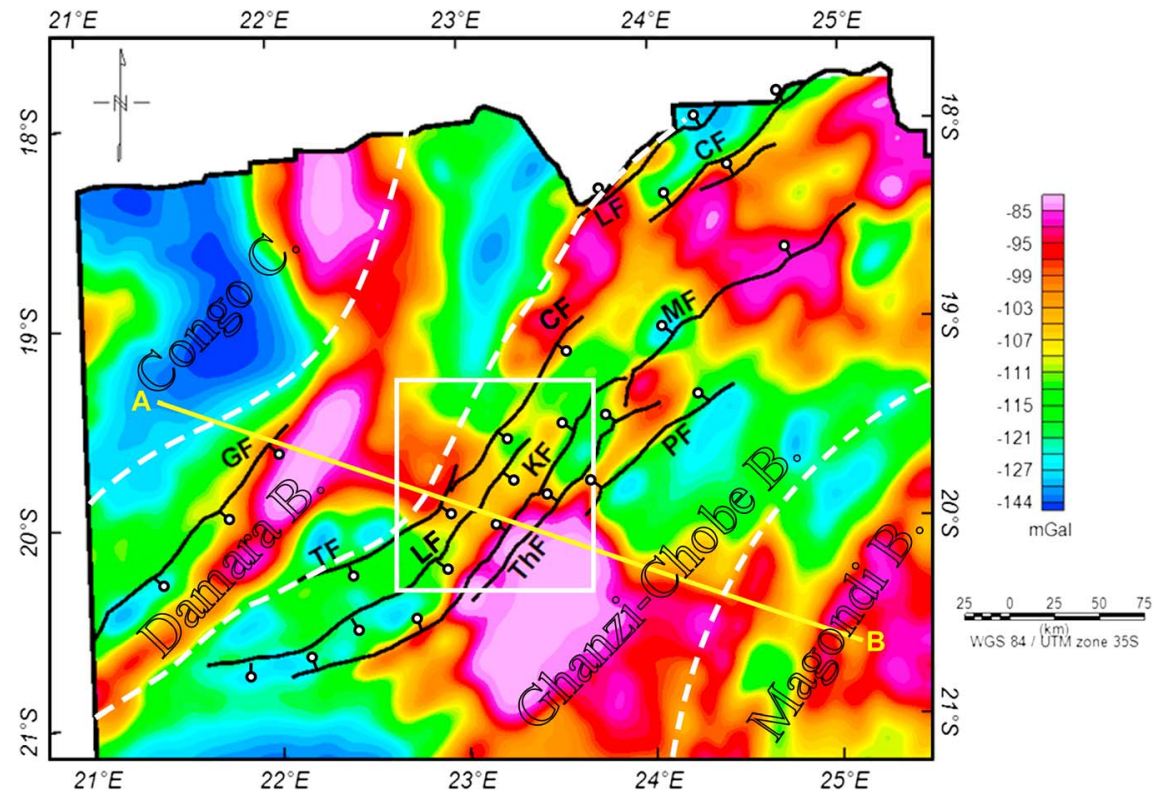

Figure 7. The Bouguer gravity anomaly map used for estimating the crustal thickness under the Okavango Rift Zone and surroundings using two-dimensional (2-D) power-density spectrum analysis. White box represents the location of the $1^{\circ} \times 1^{\circ}$ block used for the generation the power spectrum curve shown in Figure 8 . The yellow line A-B shows the trace of the cross section presented in Figure 12. Dotted white lines represent the boundaries of the Proterozoic orogenic belts. $\mathrm{LF}=\mathrm{Linyanti}$ fault; $\mathrm{GF}=$ Gumare fault; $\mathrm{CF}=\mathrm{Chobe}$ fault; $\mathrm{MF}=$ Mababe fault; $T F=$ Tsau fault; $\mathrm{LF}=\mathrm{Lech}$ fault; $\mathrm{KF}=\mathrm{Kunyere}$ fault; ThF = Thamalakane fault; $P F=$ Phuti fault; $B=$ belt.

If we assume that there are no other heat sources between the surface and the CPD as suggested by MT data [Khoza et al., 2013], then equation (2) can be reduced to

$$
D=k C / q
$$

$D, k, C$, and $q$ are as defined above.

We calculated the heat flow values at each CPD using equation (3) assuming a Curie temperature of $580^{\circ} \mathrm{C}$. Using the geology map as a guide, we varied the thermal conductivities between 1.3 and $3 \mathrm{~W} \mathrm{~m}^{-1} \mathrm{~K}^{-1}$ to match the dominant geologic unit for each CPD location. We used this range in values because they closely approximate the thermal properties of the lithologies of the Precambrian basement measured by Ballard et al. [1987] for the region. Given the uncertainties in the CPD values determined from the 3-D inversions (estimated to be between 1 and $3 \mathrm{~km}$ ) and the thermal conductivities, the heat flow values have uncertainties between 5 and $10 \mathrm{~mW} \mathrm{~m}^{-2}$. We found that the heat flow values calculated are in good agreement with values from two borehole measurements obtained by [Ballard et al., 1987] from the northeastern and southwestern parts of the ORZ.

\subsection{Moho Depth}

Available gravity data of northwestern Botswana were used to estimate crustal thickness under the ORZ and surrounding Precambrian basement. These include the $7.5 \mathrm{~km}$ grid data acquired by the Geological Survey of Botswana, data collected by various mineral exploration companies as well as 605 new gravity stations collected in this study at a $2 \mathrm{~km}$ interval in 2012 along the major roads in northwestern Botswana. The merged data were tied to the 1971 International Gravity Standardization Net [Morelli, 1996] and reduced using the 1967 International Gravity formula. Free-air and Bouguer gravity corrections were made using sea level as a datum and $2.67 \mathrm{gm} / \mathrm{cm}$ as a reduction density. The merged gravity data were gridded using the minimum curvature method at a $3 \mathrm{~km}$ interval to produce a Bouguer gravity anomaly map (Figure 7).

We used the 2-D radially averaged power spectral analysis developed by Tselentis et al. [1988] for the estimation of the thickness of the crust beneath the ORZ and the surroundings. This method has been widely used for both magnetic and gravity data [Tselentis et al., 1988; Maus and Dimri, 1996; Maden, 2010; Hussein et al., 2013]. To apply the 2-D radial-power spectrum method, a regional gravity field consisting of a first-order polynomial surface was removed from the Bouguer gravity data to produce a residual gravity 


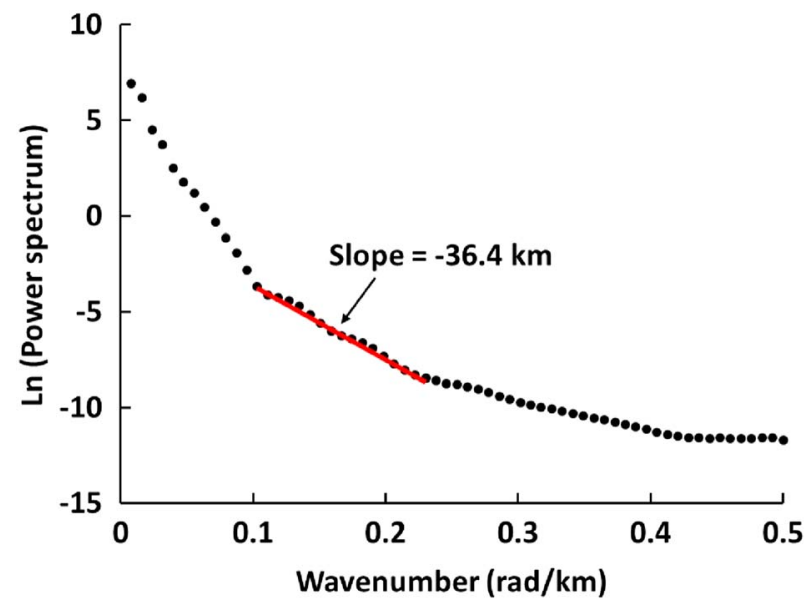

Figure 8. An example of the two-dimensional power-density spectrum analysis curve used for the estimation of the crustal thickness values. The radial-power spectrum is plotted against the wave number, and a series of points that are represented by one or more straight lines in Layer 2 on the graph are used to calculate the crustal thickness. See Figure 7 for location. anomaly. The residual gravity anomaly grid was then analyzed by calculating the radial-power spectrum of $1^{\circ} \times 1^{\circ}$ subregions $(\sim 120 \times 120 \mathrm{~km})$ with a $25 \mathrm{~km}$ overlap on all sides in order to reduce the Gibbs phenomena in which the boundaries of the subregion behave as a jump discontinuity. Hussein et al. [2013] used the power spectral analysis method to estimate CPD from magnetic data covering the Death Valley in the Western U.S. and showed that the maximum depth of the imaged anomaly source is approximately one third to one fourth of the width of the subregion used in the analysis. Therefore, we selected the subregion size to be $1^{\circ} \times 1^{\circ}$ to ensure imaging of the Moho found at depths expected for tectonic settings such as the ORZ and surroundings.

Figure 8 is an example of a radially averaged power spectrum curve of a subregion in the central part of the ORZ (Figure 7). Breaks in the slope of the power spectrum curve represent density discontinuities [Gomez-Ortiz et al., 2005]. The linear segment at the lower frequencies is assumed to be related to the Moho depth since the crust/mantle boundary represents a major density interface [Tselentis et al., 1988] since the maximum depth of the estimated density interface is directly related to the dimension of the subregion used in the investigation $(\sim 120 \times 120 \mathrm{~km}$ in this case).

To avoid uncertainties associated with selecting the part of the curve where the slope of the low wave numbers is measured (see Figure 8), three first-order polynomial fits were used to produce straight lines, and the average slope of these lines was taken to represent the Moho depth. Subsequently, the standard deviation of each fit was determined. The combination of the variations of the slope measurement from the three different polynomial fits and their standard deviations led us to determine that the error in estimating the Moho depth is $\sim \pm 3 \mathrm{~km}$.

To test the reliability of estimates of the Moho depth from the 2-D radially averaged power spectrum (Figure 8), we compared results from this study with previous studies that used passive seismic data (Table 1). For this, we calculated the crustal thickness of eight $1^{\circ} \times 1^{\circ}$ subregions centered on the locations of passive seismic stations used in estimating crustal thickness in the region by [Nguuri et al., 2001; Nair et al., 2006; Kgaswane et al., 2009]. A comparison of the results of the two approaches indicates that the Moho depth estimates from the 2-D radially averaged power spectrum method is in good agreement with those obtained from the passive

Table 1. Crustal Thickness Estimation From Gravity Compared to Data From Passive Seismic Stations in Eastern Botswana From the Kaapvaal Project

\begin{tabular}{|c|c|c|c|c|c|c|}
\hline \multirow[b]{2}{*}{ Seismic Station } & Latitude & Longitude & \multirow{2}{*}{$\begin{array}{c}\text { Gravity } \\
\text { method }(\mathrm{km})\end{array}$} & \multirow{2}{*}{$\begin{array}{l}\text { Nguuri et al. } \\
\text { [2001] (km) }\end{array}$} & \multirow{2}{*}{$\begin{array}{l}\text { Nair et al. } \\
{[2006](\mathrm{km})}\end{array}$} & \multirow{2}{*}{$\begin{array}{c}\text { Kgaswane et al. } \\
\text { [2009] (km) }\end{array}$} \\
\hline & Deg. $S^{a}$ & Deg. $E^{a}$ & & & & \\
\hline sa63 & -23.658 & 26.082 & $44.7 \pm 3$ & $50-47$ & $44.4 \pm 1.12$ & N/A \\
\hline sa64 & -22.969 & 26.202 & $45.3 \pm 3$ & $44-41$ & $41.2 \pm 0.58$ & 40.5 \\
\hline sa65 & -22.818 & 27.222 & $48.5 \pm 3$ & $50-47$ & $43.1 \pm 0.07$ & 40.5 \\
\hline sa66 & -21.900 & 26.373 & $45.4 \pm 3$ & $50-47$ & $46.9 \pm 0.16$ & 48.0 \\
\hline sa67 & -21.886 & 27.274 & $45.9 \pm 3$ & $47-44$ & N/A & 45.5 \\
\hline sa68 & -21.950 & 28.188 & $45.0 \pm 3$ & $50-47$ & $50.3 \pm 1.19$ & 45.5 \\
\hline sa70 & -21.088 & 26.335 & $54.3 \pm 3$ & $53-56$ & $51.6 \pm 0.23$ & 50.5 \\
\hline sa71 & -20.926 & 27.141 & $44.3 \pm 3$ & $47-44$ & $43.6 \pm 0.85$ & 43.0 \\
\hline
\end{tabular}

${ }^{\mathrm{a}}$ Deg. $=$ degrees. 


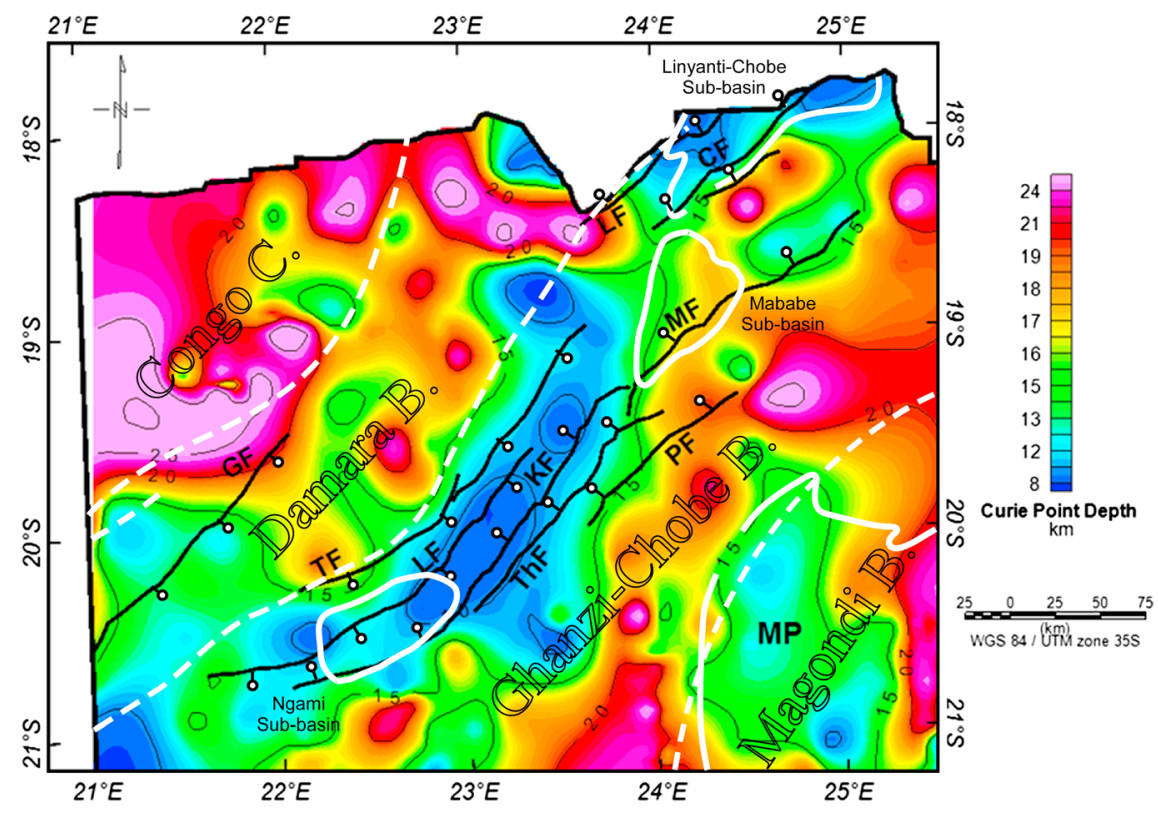

Figure 9. Curie point depth values in kilometers estimated from the three-dimensional inversion of the aeromagnetic data covering the Okavango Rift Zone (ORZ) and surroundings. Dotted white lines represent the boundaries of the Proterozoic orogenic belts. Solid white lines depict the margins of the major subbasins of the ORZ and the Makgadikgadi Pans (MP). $\mathrm{LF}=$ Linyanti fault; $\mathrm{GF}=$ Gumare fault; $\mathrm{CF}=$ Chobe fault; $\mathrm{MF}=$ Mababe fault; $\mathrm{TF}=\mathrm{Tsau}$ fault; $\mathrm{LF}=\mathrm{Lech}$ fault; $\mathrm{KF}=\mathrm{Kunyere}$ fault; $T$ hF $=$ Thamalakane fault; $P F=$ Phuti fault; $C=$ craton; $B=$ belt.

seismic data with root-mean-square (RMS) error of $2.40 \mathrm{~km}$ compared to Nguuri et al. [2001] results, $3.44 \mathrm{~km}$ compared to those of Nair et al. [2006], and $3.92 \mathrm{~km}$ compared to those of Kgaswane et al. [2009].

\section{Results}

\subsection{Curie Point Depth and Heat Flow}

Figures 9 and 10 show a well-defined NE trending zone of shallower CPDs ( 8 to $15 \mathrm{~km}$ ) and higher heat flow $\left(>55 \mathrm{~mW} \mathrm{~m}^{-2}\right.$ ) extending from the southwestern part of the Ngami subbasin to the central part of the rift zone. This zone coincides with a region of maximum subsidence within the ORZ and high concentration of normal faults [Modisi et al., 2000; Kinabo et al., 2007, 2008; Shemang and Molwalefhe, 2009]. The Linyanti-Chobe subbasin, where maximum subsidence is also observed, is characterized by the presence of lower ( 8 to $15 \mathrm{~km}$ ) CPD values and higher heat flow values (up to $83 \mathrm{~mW} \mathrm{~m}^{-2}$ ) where the concentration of normal faults appear to step northward (Figure 9). The elevated heat flow in the Linyanti-Chobe subbasin is correlated in the presence of at least one hot spring with a measured temperature of $45^{\circ} \mathrm{C}$ located to the northeast of the subbasin (grey circle in Figure 10). The overall extent of the low CPD and the high heat flow values also closely coincides with the boundary between the Neoproterozoic Damara orogenic and the Paleoproterozoic-Mesoproterozoic Ghanzi-Chobe orogenic belts. Interestingly, the Mababe subbasin, which lacks significant concentration of normal faults, is not underlain by shallow CPDs or elevated heat flow values. This suggests that the presence of a combination of Precambrian and rift structures might be needed to effectively influence the thermal structure under the ORZ.

A peculiar region of shallow CPD ( 12 to $15 \mathrm{~km})$ and elevated heat flow values $\left(\sim 50-55 \mathrm{~mW} \mathrm{~m}^{-2}\right)$ occurs beneath the Makgadikgadi Pans (Figures 9 and 10). This depression is underlain by the Paleoproterozoic Magondi and the Paleoproterozoic-Mesoproterozoic Ghanzi-Chobe orogenic belts, which are characterized by deep CPD ranging between 20 and $30 \mathrm{~km}$ and low heat flow values of $<45 \mathrm{~mW} \mathrm{~m}^{-2}$ (Figures 9 and 10). The surface topography suggests NE trending faults in this area with associated seismicity and is suggested to be a zone of extension albeit to a lesser extent than the ORZ [Baillieul, 1979]. The lithospheric thermal structure of the Makgadikgadi Pans is beyond the scope of this work, and future work can be focused on understanding the source of these anomalies. 


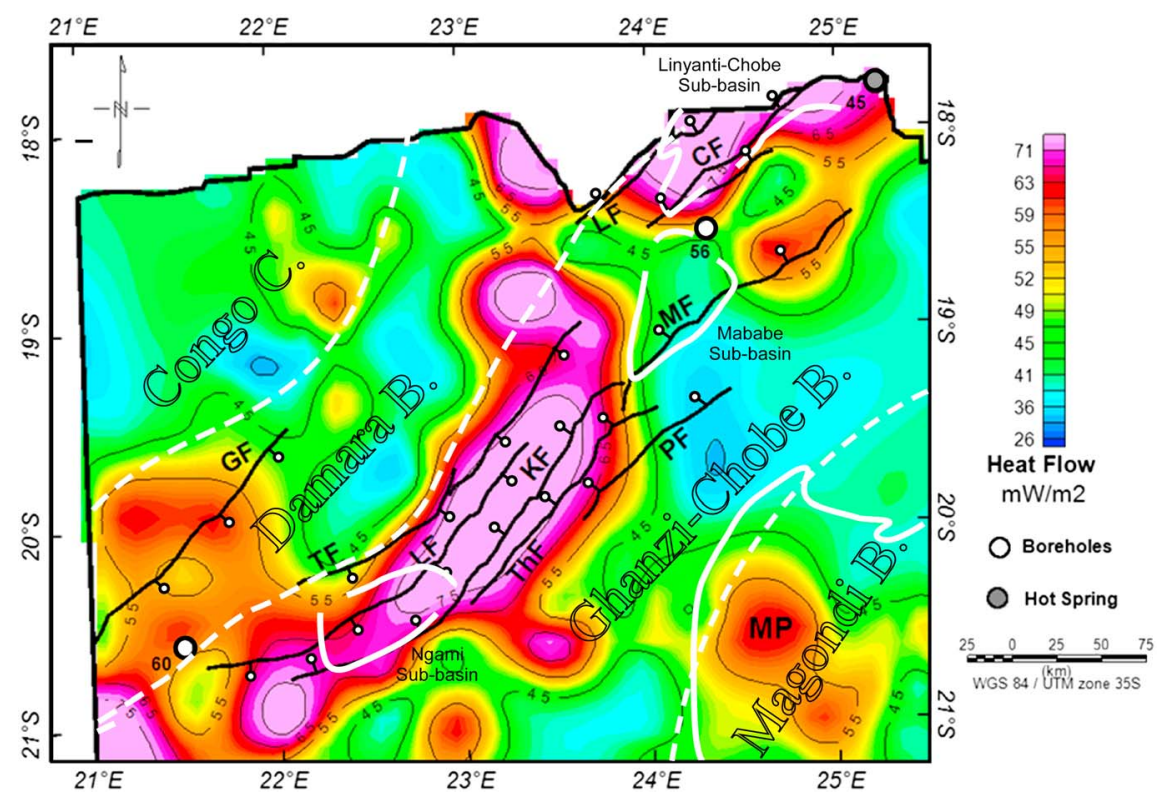

Figure 10. Heat flow values in $\mathrm{mW} \mathrm{m}^{-2}$ calculated using the Curie Point Depth obtained from the three-dimensional inversion of the aeromagnetic data covering the Okavango Rift Zone and surroundings. The white circles are locations of heat flow values obtained from borehole measurement by Ballard et al. [1987]. The grey circle is the location of a hot spring with temperature of $45^{\circ} \mathrm{C}$. Dotted white lines represent the boundaries of the Proterozoic orogenic belts. Solid white lines depict the margins of the major subbasins of the ORZ and the Makgadikgadi Pans (MP). LF = Linyanti fault; $\mathrm{GF}=$ Gumare fault; $\mathrm{CF}=$ Chobe fault; $\mathrm{MF}=$ Mababe fault; $T F=$ Tsau fault; $\mathrm{LF}=$ Lecha fault; $\mathrm{KF}=$ Kunyere fault; $\mathrm{ThF}=$ Thamalakane fault; $\mathrm{PF}=$ Phuti fault; $\mathrm{C}=$ craton; $\mathrm{B}=$ belt.

The deepest CPD values $(20-30 \mathrm{~km})$ and lowest heat flow values $\left(<45 \mathrm{~mW} \mathrm{~m}^{-2}\right)$ covering a relatively vast and continuous region are found to the northwest of the ORZ (Figures 9 and 10). These anomalies closely coincide with the continuation of the Archean Congo craton in northwestern Botswana as well as portions of the NE trending Neoproterozoic Damara orogenic belt on the southeastern margin of the craton (Figures 9 and 10).

\subsection{Moho Depth}

Figure 11 presents the Moho depth estimates of the 2-D radially averaged spectrum analysis of the gravity data showing that the crustal thickness under the ORZ and the surrounding Precambrian basement ranges between 25 and $50 \mathrm{~km}$. The shallowest Moho depth values ( 26 to $32 \mathrm{~km}$ ) are found within the Ngami and the Linyanti-Chobe subbasins in the northeastern and southwestern parts of the ORZ. Shallow Moho depths $(\sim 30-35 \mathrm{~km})$ are also found beneath the Makgadikgadi Pans. Moho depth estimates greater than $40 \mathrm{~km}$ occur outside the rift under the Precambrian basement (compare Figures 11 and $3 b$ ).

\section{Discussion}

\subsection{Thermal Structure Beneath the ORZ and Surrounding Basement}

We have used CPD estimates obtained by inverting magnetic data for 3-D magnetic susceptibility distributions to estimate heat flow values to evaluate the thermal structure beneath the ORZ and surrounding Proterozoic basement in order to elucidate processes responsible for initiating the rift. We also estimate the Moho depths beneath the study region. The 3-D inversion models provide spatially detailed depths to the bottom of the magnetic sources (e.g., Figures 6 and 10). The variability in the depths obtained and heat flow values estimated are reflective of the different tectonic elements of the basement geology consistent with the notion that CPD analyses can be used to estimate the thermal and/or geologic structure of a region [Hussein et al., 2013]. The CPD values could also be a response to the variations in crustal thickness. Figures 9 and 10 show that shallower CPD values $(<15 \mathrm{~km})$ and elevated heat flow values $\left(>55 \mathrm{~mW} \mathrm{~m}^{-2}\right)$ occur within the rift zone, whereas deeper CPD values $(>15 \mathrm{~km})$ and lower heat flow estimates $\left(<50 \mathrm{~mW} \mathrm{~m}^{-2}\right)$ values occur outside the rift beneath the surrounding Proterozoic mobile belts. Arnaiz-Rodrigues and Orihuela [2013] classified the 


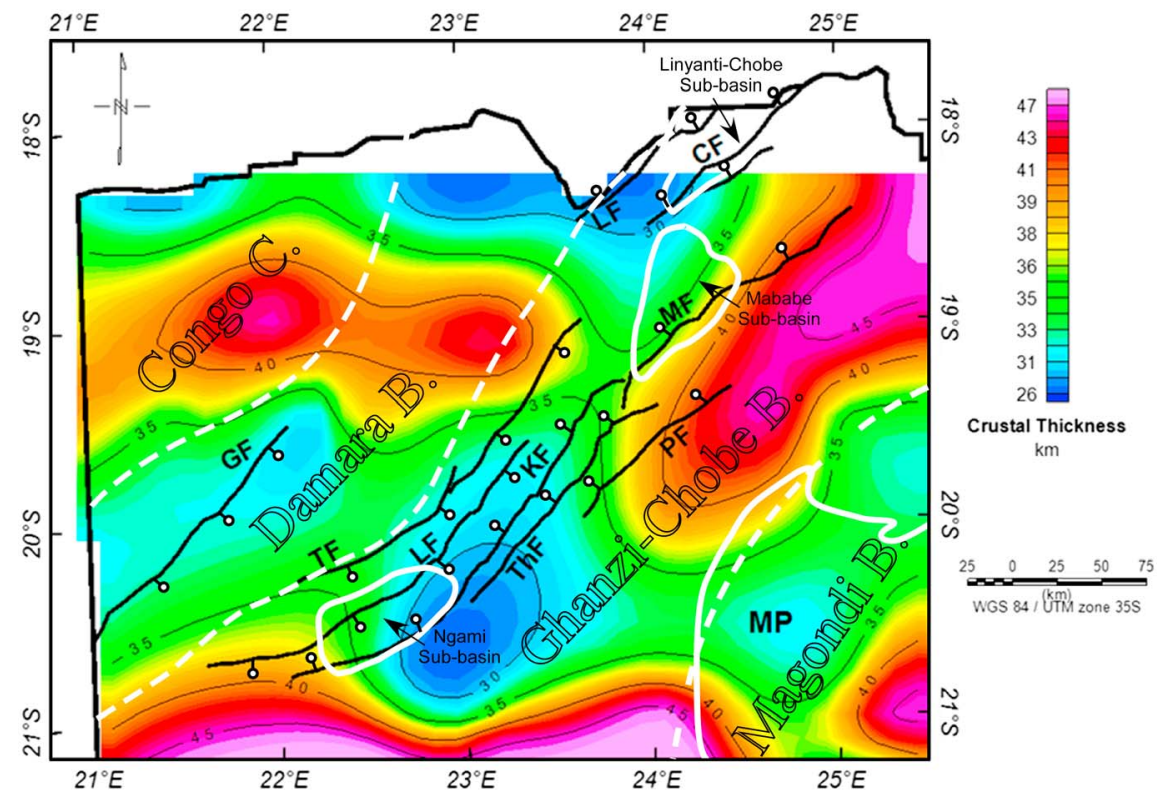

Figure 11. Crustal thickness in kilometers obtained from the two-dimensional analysis of the gravity data covering the Okavango Rift Zone and surroundings. Dotted white lines represent the boundaries of the Proterozoic orogenic belts. Solid white lines depict the margins of the major subbasins of the ORZ and the Makgadikgadi Pans (MP). LF = Linyanti fault; $\mathrm{GF}=$ Gumare fault; $\mathrm{CF}=$ Chobe fault; $\mathrm{MF}=$ Mababe fault; $\mathrm{TF}=\mathrm{Tsau}$ fault; $\mathrm{LF}=$ Lecha fault; $\mathrm{KF}=$ Kunyere fault; $\mathrm{ThF}=$ Thamalakane fault; $\mathrm{PF}=$ Phuti fault; $\mathrm{C}=$ craton; $\mathrm{B}=$ belt

CPD values into two groups based on their position relative to the Moho depth: (1) CPD values shallower than the Moho are usually associated with areas with high heat flow resulting from crustal thinning due to extension/rifting, and (2) CPD values deeper than the Moho are typical of tectonically and isostatically stable areas with low heat flow such as shields and cratons. Therefore, variations in the CPD values can be correlated with the tectonic processes, especially thermal processes driving rift initiation. Shallow CPD values have been interpreted as due to heating of the continental crust, typically by underlying magma chambers. For example, shallow CPD values ranging between 5.2 and $8.3 \mathrm{~km}$ from the eastern branch of the EARS in the southern Kenya rift (Figure 1) have been interpreted as indicating high heat flow associated with the presence of a magma body at depth [Githiri et al., 2012]. Similarly, CPD estimates from the Death Valley and surrounding areas in the United States showed that the shallowest CPD values $(<15 \mathrm{~km})$ occur over known geothermal fields, hot springs, and a seismically imaged magmatic body [Hussein et al., 2013].

Our heat flow estimates are similar to those reported from the Kivu, Tanganyika, and Malawi rifts of the western branch of the EARS (Figure 1) ranging between 53 and $82 \mathrm{~mW} \mathrm{~m}^{-2}$ [Fadaie and Ranalli, 1990]. Our estimates are also consistent with the measured heat flow values of Ballard et al. [1987]. For example, southeast of the southern termination of the Chobe fault ( $18^{\circ} 31$ ' $\mathrm{S}, 24^{\circ} 19^{\prime} \mathrm{E}$, Figure 10 , filled white circle), our estimated heat flow of $60 \mathrm{~mW} \mathrm{~m}^{-2}$ is comparable to the $\sim 56 \mathrm{~mW} \mathrm{~m}^{-2}$ value obtained from borehole data. Furthermore, our estimated heat flow value of $\sim 53 \mathrm{~mW} \mathrm{~m}^{-2}$ for a site west of the southern termination of the Lecha fault $\left(20^{\circ} 35^{\prime} \mathrm{S}, 21^{\circ} 28^{\prime} \mathrm{E}\right.$, Figure 10 , filled white circle) is comparable to the $60 \mathrm{~mW} \mathrm{~m}^{-2}$ value measured in boreholes by Ballard et al. [1987]. This region of elevated heat flow extends to the southwest of the study site into Namibia. Within the Damaran belt in Namibia, heat flow values from borehole measurements range between 56 and $92 \mathrm{~mW} \mathrm{~m}^{-2}$ [Ballard et al., 1987], suggesting that the Damaran belt is characterized by higher heat flow compared to the surrounding cratons.

What is clear from our study is that the shallow CPD values under the ORZ is strongly correlated with the presence of major rift-related border faults and the boundary between Proterozoic orogenic belts (Figure 9). The shallowest CPD values ( $8-10 \mathrm{~km}$ ) occur within a region bounded by the Tsau and Thamalakane faults in the southwest and within the Chobe and Linyanti faults in the northeast (Figure 9). Previous investigations using depth to basement estimations from gravity and magnetic data [Kinabo et al., 2007] and high-resolution shallow MT measurements [Mosley-Bufford et al., 2012] have suggested that most of the subsidence is taking 
place within the $\sim 60 \mathrm{~km}$ wide zone bounded by the Tsau and Thamalakane faults. This zone also closely coincides with the boundary between the Damara belt to the northwest and the Ghanzi-Chobe belt to the southeast.

Not surprisingly, the shallow CPD values are accompanied by high heat flow typically higher than $55 \mathrm{~mW} \mathrm{~m}^{-2}$ (Figure 10). Our first-order interpretation is that these high heat flow values are only associated with the rifted region. However, there is the possibility that high heat flow estimates are also associated with Proterozoic orogenic belts. For example, Ballard et al. [1987] reported average heat flow values from borehole measurements for 25 sites in Botswana and Namibia. These values are $<40 \mathrm{~mW} \mathrm{~m}^{-2}$ within the cratons which increase to $\sim 60 \mathrm{~mW} \mathrm{~m}^{-2}$ at the craton margins and to $>70 \mathrm{~mW} \mathrm{~m}^{-2}$ within the Proterozoic orogenic belts. Heat flow measurements at the surface of the Earth comprise three components: (1) radiogenic decay of heat-producing elements such as $\mathrm{K}$, Th, and $\mathrm{U},(2)$ heat conducted through the lithosphere from the underlying mantle, and (3) orogenic heat, transported by convection from magmas and mantle fluids into the lithosphere during orogenic events [Rudnick et al., 1998 and references therein]. It is therefore important in the interpretation of heat flow data to acknowledge these three components of surface heat flow. Chapman and Pollack [1975, 1977] and Ballard et al. [1987] acknowledging these three different sources of heat flow, argued that the variations in heat flow cannot be accounted for by crustal heat production (component (1) above) and that part of this heat flow may originate from greater depths, suggesting a possible fundamental difference in the thermal structure of the lithosphere between the cratons and the orogenic belts in this part of Africa.

High heat flow estimates were also obtained from other parts of the EARS that are underlain by Proterozoic orogenic belts. Sebagenzi et al. [1993] obtained heat flow values ranging between 48 and $72 \mathrm{~mW} \mathrm{~m}^{-2}$ from the Neoproterozoic orogenic belt in southeastern Congo, close to what was later identified as the Mweru rift (Figure 1). Sebagenzi et al. [1993] argued that these values are higher than what is expected for a Proterozoic orogenic belt and suggested that these values are due to lithospheric thinning accompanying a southwestern extension of the EARS. Table 1 shows that our Moho depth estimates are comparable to depths obtained from seismic studies. The Moho depth estimates from spectral analysis suggest that the crust is shallower below the ORZ coincident with the shallow CPD values and elevated heat flow than the adjacent Proterozoic mobile belts. Interestingly, beneath the ORZ in the vicinity of the Ngami subbasin, we estimated the crustal thickness to be $\sim 30 \mathrm{~km}$ (Figure 11). A shallower crust beneath other amagmatic rift segments has been observed for the western branch of the EARS within a region dominated by low $P$ wave velocity (3-5\% decrease) in the middle crust and the upper mantle lithosphere interpreted as resulting from a melt fraction of $\sim 2 \%-3.3 \%$ or by a temperature increase of at least 248 to $376 \mathrm{~K}$ [Wölbern et al., 2012; Jakovlev et al., 2013].

\subsection{Source of the Thermal Anomalies Beneath the ORZ}

Assuming that the CPD values in Figure 9 are not due to the lack of magnetic minerals, these results together with the heat flow data suggest that the lithosphere beneath the ORZ is thermally altered compared to the surrounding basement rocks. The occurrence of electrical and magnetic anomalies along portions of the Damara-Ghanzi-Chobe belt has been consistently observed in geophysical surveys. However, the origin of this conductive anomaly remains debatable even with new MT data. Magnetometer array studies [De Beer et al., 1975] have indicated strong electrical conductors within the crust in northern Botswana with the spatial location of this conductive anomaly aligned with our CPD and heat flow anomalies. de Beer et al. [1975] suggested that the origin of the conductivity anomaly may be either thermal or compositional or both, the former being associated with anomalously high temperatures in the crust and upper mantle and the latter with conductive materials such as graphite or sulfides often concentrated within fracture zones. Chapman and Pollack [1977], citing elevated heat flow measurements over Zambia along the trend of the conductivity anomaly, suggested that the origin of the conductive anomaly may be at least partly thermal due to a thinned lithosphere from rifting. This interpretation is in contrast with recent MT results suggesting that the ORZ lacks a typical rift signature of a thinned lithosphere coupled with the presence of a thermal anomaly [Khoza et al., 2013]. Khoza et al. [2013] argued that if rifting is indeed taking place in the ORZ, then it must be initiated through uppermost crustal processes without the involvement of asthenospheric processes. Ritter et al. [2003] and Khoza et al. [2013] interpreted middle to shallow crustal conductors within the central zone of the Damara-Ghanzi-Chobe belt as either due to the presence of graphite-bearing marbles or massive 


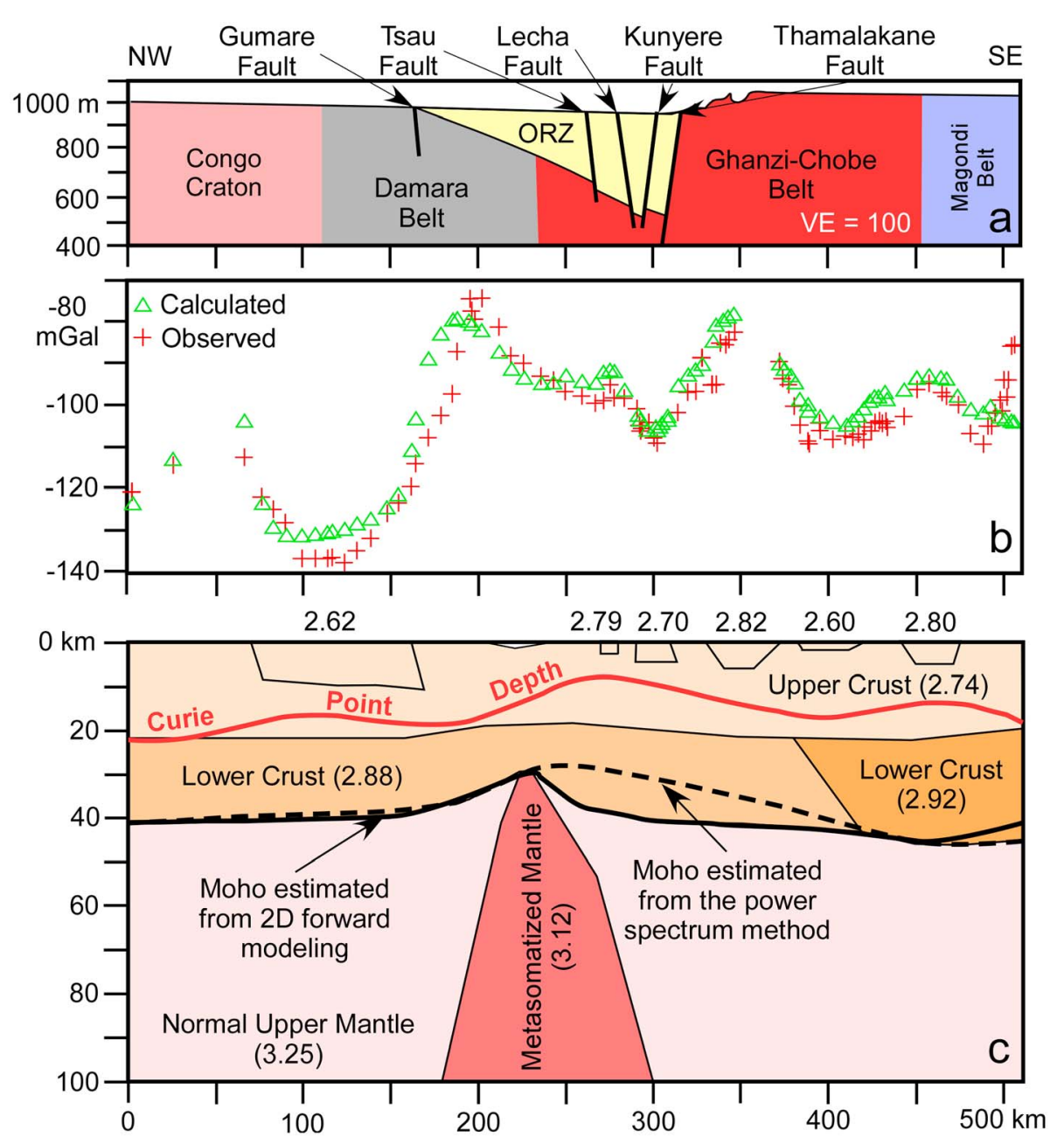

Figure 12. (a) An idealized NW-SE geological cross section of the Okavango Rift Zone (ORZ) and the underlying Precambrian cratons and orogenic belts along the baseline shown as A-B in Figure 7. (b) Observed and calculated (based on the two-dimensional (2-D) forward model shown in Figure 12c) Bouguer gravity anomalies along the same baseline of the geological cross section shown in Figure 12a. (c) A 2-D forward model showing the lithospheric structure under the ORZ and surroundings. The dashed black line shows the Moho depth estimated from the 2-D power spectrum analysis of the gravity data covering the ORZ and surroundings. The red solid line shows the Curie point depth (CPD) estimated from the three-dimensional (3-D) inversion of the aeromagnetic data covering the ORZ and surroundings. The values in parentheses are densities in $\mathrm{gm} / \mathrm{cm}^{3}$.

sulfide mineralization. We note that similar crustal conductors have been observed in Tibet coincident with locations of major shear zones and interpreted as resulting from elevated fluid content that enhance deformation by weakening the crust [Bai et al., 2010].

Our results show that the ORZ is associated with shallow CPDs, elevated heat flow, and elevated Moho, within a $60 \mathrm{~km}$ narrow zone marking the southeastern margin of the ORZ (Figures 9-11). Hence, in the absence of surface magmatism and lack of a MT signature diagnostic of a thinned lithosphere, a possible interpretation is that the source of the thermal anomaly beneath the ORZ is caused by fluid infiltration concentrated along the lithospheric-scale zone of weakness presented by the boundary between the Damara and Ghanzi-Chobe belt. The Damara orogenic belt represents a lithospheric-scale suture zone developed during the Neoproterozoic final stages of amalgamation of the Greater Gondwana fragments, notably the collision between the Congo and Kalahari cratons [Gray et al., 2008]. The presence of such structures is capable of providing conduits for upward migration of fluids throughout the lithospheric column. The amount and origin of fluids (mostly $\mathrm{H}_{2} \mathrm{O}$ and $\mathrm{CO}_{2}$ ) in the lithosphere is actively debated but could represent metamorphic fluids released from active dehydration reactions or infiltrating water from the surface. Some studies have highlighted the importance of the upward migration of mantle fluids in triggering earthquakes 
and in active crustal deformation given the presence of interconnected fractures. For example, Gold and Soter [1984-1985] discussed that, in the absence of deep fractures, fluids in the lithosphere migrate through diffusion, a mechanism not effective in upward migration of these fluids. The presence of deep fractures allows for these fluids to concentrate, forming what is referred to by Gold and Soter [1984-1985] as the "fluid domain" in which the concentration of the fluids reaches a level capable of inducing enough pressure to open fractures (analogous to hydraulic fracturing). This upward migration of the fluids ultimately triggers earthquakes through sudden slip. Kennedy et al. [1997] showed from a helium isotope study in the San Andreas fault system that mantle fluids can enter the lower crust through brittle fractures rather than by diffusion. Subsequently, Kennedy and van Soest [2007] used helium isotope study in the Basin and Range Province to show that there is a direct correlation between the increased mantle fluid concentration and the increased rate of extension in what is referred to as "deformation-enhanced permeability." Our proposed conceptual model (Figure 12) of hot fluids resulting in a metasomatized (probably mineralized) subcontinental lithospheric mantle is consistent with recent observations made from seismic data beneath the Albertine rift [Wölbern et al., 2012; Jakovlev et al., 2013]. Here a 3-5\% reduction in $P$ wave velocity beneath the rift is interpreted as resulting from either a $2-3 \%$ melt fraction or temperature increase of $248-376 \mathrm{~K}$. The transport of these fluids upward is enhanced by a network of vertically oriented intersections of preexisting faults accompanied by pressure perturbations that trigger earthquakes Jakovlev et al. [2013].

Our findings are summarized in a schematic cross section in Figure 12. To test the validity of our conceptual model in terms of Moho depth and possible compositional variation of the subcontinental lithospheric mantle under the ORZ, we performed a 2-D forward gravity model along profile A-B (Figure 7). Because gravity models are nonunique, constraints such as rock densities, thickness, and lateral variations of rock units must be used to construct meaningful geological models. Constraints in the ORZ and the surrounding Precambrian basement are not readily available. For this reason, the crustal thicknesses obtained from the spectral analysis were used as initial constraints in the first iteration of the 2-D forward modeling of the gravity data. Further, the thicknesses and densities of the upper $\left(2.74 \mathrm{gm} / \mathrm{cm}^{3}\right)$ and lower crust $(2.88$ and $2.92 \mathrm{gm} / \mathrm{cm}^{3}$ ) were estimated from gravity and seismic investigations in other parts of the EARS [e.g., Simiyu and Keller, 2001; Mickus et al., 2007]. Finally, upper crustal bodies of various dimensions and densities were introduced in the model to account for lithological variations in the Damara, Ghanzi-Chobe, and Magondi orogenic belts as well as sediment accumulation within Karoo basins as indicated by geological studies [Singletary et al., 2003; Mapeo et al., 2006]. Given the uncertainties of the density, geometry, and dimension of these bodies, these parameters were varied by $10 \%$ in the modeling process.

The 2-D forward modeling of the gravity data (Figures 12a-12c) shows Moho depths comparable to those obtained from the 2-D power spectrum analysis of gravity data, especially under the ORZ and the region to the northwest of it (Figure 12c). However, there is a discrepancy between the Moho depth results of the two methods in the region to the southeast of the ORZ (Figure 12c). We attribute this discrepancy to the challenges of the 2-D modeling arising from the presence of numerous short wavelength anomalies (Figure 12b), possibly associated with upper crust lithological variations within different orogenic belts as well as the presence of Karoo sedimentary rocks covering the Precambrian basement (Figure 12c). The ORZ gravity signature depicts an asymmetrical Bouguer gravity low with gravity anomalies reaching -60 to $-80 \mathrm{mGal}$ at the margins of the rift. The asymmetry of the gravity anomaly matches the half-graben geometry of the ORZ (Figures $12 \mathrm{a}$ and $12 \mathrm{~b}$ ). We found that this gravity signature is best modeled by the inclusion of a slightly lighter $\left(3.12 \mathrm{gm} / \mathrm{cm}^{3}\right)$ altered mantle under the ORZ surrounded by normal mantle with $3.25 \mathrm{gm} / \mathrm{cm}^{3}$ density (Figure 12c). This is consistent with alteration due to upward migration of hot fluids. The final model represents one geological reasonable model that fits the observed data given the available constraints. Thus, we surmise that the presence of strong basement fabric and weak zones, especially at the boundaries between the Damara and Ghanzi-Chobe belts, might have facilitated the upward migration of hot fluid, hence locally increasing the geothermal gradient in this region as observed by the shallow CPD values and elevated heat flow, softening the lithosphere, and allowing for strain localization initiating the rift.

\section{Conclusion}

Three-dimensional inversion of aeromagnetic data and 2-D power spectrum analysis of gravity data covering the amagmatic ORZ, a nascent segment in the EARS, have shown that this extensional structure is underlain 
by shallow CPD values $(<15 \mathrm{~km})$, elevated heat flow $\left(>50 \mathrm{~mW} \mathrm{~m}^{-2}\right)$, and thin continental crust $(\sim 30 \mathrm{~km})$. These observations are similar to the more well-developed magmatic segments of the EARS. Comparing these observations with MT results that do not support the presence of magmatic bodies or an elevated asthenosphere under the ORZ requires an alternative source (other than magma ascending from an elevated asthenosphere) to explain the anomalous thermal structure of the lithosphere under the ORZ. We hypothesize that hot mantle fluids ascending through major lithospheric zones of weakness presented by penetrative Proterozoic structures (including suture zones) associated with the Proterozoic orogenic belts that underlie the ORZ may explain the shallow CPD value, elevated heat flow, and thin crust beneath the ORZ. Additional geophysical (active and passive seismic and magnetotelluric) studies and numerical modeling to be completed as part of the Project for Rift Initiation Development and Evolution is needed in the ORZ to address what is potentially a paradigm shift for amagmatic rifts suggesting that rifting can be initiated entirely within the lithosphere without the involvement of asthenospheric processes and/or magmatic fluids. Instead, we propose a major role of fluids in weakening the lithosphere and localizing strain during the initial stages of rifting.

\section{Acknowledgments}

This project is funded by the National Science Foundation-Continental Dynamics grant EAR 1255233 and is part of the Project for Rift Initiation Development and Evolution (PRIDE). The Geological Survey of Botswana allowed free access to the airborne magnetic data and Bouguer gravity anomaly data. Gravity data acquired as part of this project will be available at the GeoPRISM website. We thank K. Matende, K. Obenberger, G. Motseokae, and B. Montshwiwa for field assistance. A. LePera helped with the figures. We thank G.R. Keller and an anonymous reviewer for their critical comments that substantively improved the manuscript. The University of Botswana and the Botswana Geological Survey provided logistical support. This is the Boone Pickens School of Geology contribution 2015-15.

\section{References}

Aboud, E., A. Salem, and M. Mekkawi (2011), Curie depth map for Sinai Peninsula, Egypt deduced from the analysis of magnetic data, Tectonophysics, 506, 46-54.

Arnaiz-Rodrigues, M. S., and N. Orihuela (2013), Curie point depth in Venezuela and the Eastern Caribbean, Tectonophysics, 590, 38-51. Aubourg, C., G. Tshoso, B. Le Gall, H. Bertrand, J. Tiercelin, A. Kampunzu, and M. Modisi (2008), Magma flow revealed by magnetic fabric in the Okavango giant dyke swarm, Karoo igneous province, northern Botswana, J. Volcanol. Geotherm. Res., 170, $247-261$.

Bai, D. H., et al. (2010), Crustal deformation of the eastern Tibetan Plateau revealed by magnetotelluric imaging, Nat. Geosci., 3, $358-362$. Baillieul, T. A. (1979), Makgadikgadi Pans Complex of central Botswana, Geol. Soc. Am. Bull., 90, 289-312.

Ballard, S., H. N. Pollack, and N. J. Skinner (1987), Terrestrial heat flow in Botswana and Namibia, J. Geophys. Res., 92, 6291-6300, doi:10.1029/ JB092iB07p06291.

Begg, G. C., et al. (2009), The lithospheric architecture of Africa: Seismic tomography, mantle petrology, and tectonic evolution, Geosphere, 5 , 23-50, doi:10.1130/GES00179.1.

Bhattacharyya, B. K. (1964), Magnetic anomalies due to prism-shaped bodies with arbitrary polarization, Geophysics, 29, 517-553.

Bhattacharyya, B. K., and L. K. Leu (1975), Analysis of magnetic anomalies over Yellowstone National Park: Mapping of Curie point isothermal surface for geothermal reconnaissance, J. Geophys. Res., 80, 4461-4465, doi:10.1029/JB080i032p04461.

Bialas, R., W. R. Buck, and R. Qin (2010), How much magma is required to rift a continent, Earth Planet. Sci. Lett., 292, 68-78.

Blakely, R. J. (1988), Curie temperature isotherm analysis and tectonic implications of aeromagnetic data from Nevada, J. Geophys. Res., 93, 11,817-11,832, doi:10.1029/JB093iB10p11817.

Bouligand, C., J. Glen, and R. Blakely (2009), Mapping Curie temperature depth in the western United States with a fractal model for crustal magnetization, J. Geophys. Res., 114, doi:10.1029/2009JB006494.

Buck, W. R. (2006), The role of magma in the development of Afro-Arabian Rift System, J. Geol. Soc. London, $259,43-54$.

Byerly, P. E., and R. Stolt (1977), An attempt to define the Curie point isotherm in Northern and central Arizona, Geophysics, 42, 1394-1400.

Calais, E., C. J. Ebinger, C. Hartnady, and J. M. Nocquet (2006), Kinematics of the East African Rift from GPS and earthquake slip vector data, J. Geol. Soc. London, 259, 9-22.

Chandrajith, R., J. A. C. Barth, N. D. Subasinghe, D. Merten, and C. B. Dissanayake (2013), Geochemical and isotope characterization of geothermal spring waters in Sri Lanka: Evidence for steeper than expected geothermal gradients, J. Hydrol., 476, 360-369.

Chapman, D., and H. N. Pollack (1975), Global heat flow: A new look, Earth Planet. Sci. Lett., 28, 23-32.

Chapman, D. A., and H. N. Pollack (1977), Heat flow and heat production in Zambia: Evidence for lithospheric thinning in Central Africa, Tectonophysics, 41, 79-100.

Chorowicz, J. (2005), The East Africa rift system, J. Afr. Earth Sci., 43, 379-410.

Craig, T. J., J. A. Jackson, K. Priestley, and D. McKenzie (2010), Earthquake distribution pattern in Africa: Their relationship to variations in lithospheric and geological structure, and their rheological implications, Geophys. J. Int., 185, 403-434.

de Beer, J., D. Gough, and J. van Zijl (1975), An electrical conductivity anomaly and rifting in southern Africa, Nature, 255, 678-680.

Ebinger, C. (2005), Continental break-up: The East African perspective, Astron. Geophys., 46, 2.16-12.21, doi:10.1111/j.1468-4004.2005.46216.x.

Ebinger, C. J., and M. Casey (2001), Continental break-up in magmatic provinces: An Ethiopian example, Geology, 29, 527-530.

Fadaie, K., and G. Ranalli (1990), Rheology of the lithosphere in the East-African Rift System, Geophys. J. Int., 102, $445-453$.

Frost, B., and P. Shive (1986), Magnetic mineralogy of the lower continental crust, J. Geophys. Res., 48, 376-390.

Furlong, K. P., W. Spakman, and R. Wortel (1995), Thermal structure of the continental lithosphere: Constrains from seismic tomography, Tectonophysics, 244, 107-117.

Gamrod, J. (2009), Paleolimnological records of environmental change preserved in Paleo-Lake Mababe, northwest Botswana, MS thesis, Oklahoma State Univ., Stillwater.

Githiri, J. G., J. P. Patel, J. O. Barongo, and P. K. Karanja (2012), Spectral analysis of ground magnetic data in Magadi area, Southern Kenya Rift, Tanzania J. Sci., 38, 1-14.

Gold, T., and S. Soter (1984-1985), Fluid ascent through the solid lithosphere and its relation to earthquakes, Pure Appl. Geophys., 122, 492-530.

Gomez-Ortiz, D., R. Tejero-Lopez, R. Babin-Vich, and A. Rivas-Ponce (2005), Crustal density structure in the Spanish Central System derived from gravity data analysis (Central Spain), Tectonophysics, 403, 131-149.

Gray, R. D., D. A. Foster, J. G. Meert, B. D. Goscombe, R. Armstrong, R. A. J. Trouw, and C. W. Passchier (2008), A Damara orogeny perspective on the assembly of southwestern Gondwana, Geol. Soc. London Spec. Publ., 294, 257-278.

Haggerty, S. (1978), Mineralogical constraints on Curie isotherms in deep crustal magnetic anomalies, Geophys. Res. Lett., 5, 105-108, doi:10.1029/GL005i002p00105. 
Horner-Johnson, B. C., R. G. Gordon, and D. F. Argus (2007), Plate kinematic evidence for the existence of a distinct plate between the Nubia and Somalian plates along the Southwest Indian Ridge, J. Geophys. Res., 112, B05418, doi:10.1029/2006JB004519.

Hunt, C., B. Moskowitz, and S. Banerjee (1995), Magnetic properties of rocks and minerals, in Rock Physics \& Phase Relations: A Handbook of Physical Constants, pp. 189-204, AGU, Washington, D. C.

Hussein, M., K. Mickus, and F. L. Serpa (2013), Curie point depth estimates form aeromagnetic data from Death Valley and surrounding regions, California, Pure Appl. Geophys., 170, 617-632.

Jakovlev, A., G. Rümpker, M. Lindenfeld, I. Koulakov, A. Schumann, and N. Ochmann (2013), Crustal seismic velocities of the Rwenzori Region, East African Rift, from local travel-time Tomography: Evidence for low-velocity anomalies beneath the mountain Range, Bull. Seismol. Soc Am., 101, 848-858.

Kendall, J. M., G. W. Stuart, C. J. Ebinger, I. D. Bastow, and D. Keir (2005), Magma assisted rifting in Ethiopia, Nature, 433, $146-148$.

Kennedy, B. M., and M. van Soest (2007), Flow of mantle fluids through the ductile lower crust: Helium isotope trends, Science, 318, 1433, doi:10.1126/science.1147537.

Kennedy, B. M., Y. K. Kharaka, W. C. Evans, A. Ellwood, D. J. DePaolo, J. Thordsen, G. Ambats, and R. H. Mariner (1997), Mantle fluids in the San Andreas fault system, California, Science, 278, 1278, doi:10.1126/science.278.5341.1278

Key, R. M., and N. Ayres (2000), The 1998 edition of the National Geological Map of Botswana, J. Afr. Earth. Sci., 30, 427-451.

Kgaswane, E. M., A. A. Nyblade, J. Julia, P. H. G. M. Dirks, R. J. Durrheim, and M. E. Pasyanos (2009), Shear wave velocity structure of the lower crust in southern Africa: Evidence from compositional heterogeneity within Archean and Proterozoic terrain, J. Phys. Earth, 114, 1978-2012, doi:10.1029/2008JB006217.

Khoza, D., A. G. Jones, M. R. Muller, R. L. Evans, S. J. Webb, M. Miensopust, and the SAMTEX team (2013), Tectonic model of the Limpopo belt: Constraints from magnetotelluric data, Precambrian Res., 226, 143-156.

Kinabo, B. D., E. A. Atekwana, J. P. Hogan, M. P. Modisi, D. D. Wheaton, and A. B. Kampunzu (2007), Early structural development of the Okavango rift zone, NW Botswana, J. Afr. Earth. Sci., 48, 125-136.

Kinabo, B. D., J. P. Hogan, E. A. Atekwana, M. G. Abdelsalam, and M. P. Modisi (2008), Fault growth and propagation during incipient continental rifting: Insights from a combined aeromagnetic and Shuttle Topography Mission digital elevation model investigation of the Okavango Rift Zone, northwest Botswana, Tectonics, 27, 1-16, doi:10.1029/2007TC002154.

Li, Y., and D. W. Oldenburg (1996), 3-D inversion of magnetic data, Geophysics, 61, 394-408.

Lillie, R. J. (1999), Whole Earth Geophysics-An Introductory Textbook for Geologists and Geophysicists, Prentice Hall, Upper Saddle River, N. J. Maden, N. (2010), Curie-point depth from spectral analysis of magnetic data in Erciyes Stratovolcano (Central Turkey), Pure Appl. Geophys., 167, 349-358.

Mapeo, R., L. Ramokate, F. Corfu, D. Davis, and A. Kampunzu (2006), The Okwa basement complex, western Botswana: U-Pb zircon geochronology and implications for Eburnean processes in southern Africa, J. Afr. Earth. Sci., 46, 253-262.

Maus, S., and V. P. Dimri (1996), Potential field power spectrum inversion for scaling geology, J. Geophys. Res., 100, 12,605-12,616, doi:10.1029/95JB00758

McCarthy, T. S., and W. N. Ellery (1998), The Okavango Delta, Trans. R. Soc. S. Afr., 53, 157-182.

McCarthy, T. S., M. Barry, A. Bloem, W. N. Ellery, H. Heister, C. L. Merry, H. Ruther, and H. Sternberg (1997), The gradient of the Okavango fan, Botswana, and its sedimentological and tectonic implications, J. Afr. Earth. Sci., 24, 65-78.

Mickus, K., K. Tadesse, G. Keller, and B. Oluma (2007), Gravity analysis of the Main Ethiopian Rift, J. Afr. Earth. Sci., 48, 59-69.

Miensopust, M. P., A. G. Jones, M. Muller, X. Garcia, and R. L. Evans (2011), Lithospheric structures and Precambrian terrane boundaries in northeastern Botswana revealed through magnetotelluric profiling as part of the southern African magnetotelluric experiment, J. Geophys. Res., 116, B02401, doi:10.1029/2010JB007740.

Modie, B. (2000), Geology and mineralization in the Meso- to Neoproterozoic Ghanzi-Chobe belt of northwest Botswana, J. Afr. Earth. Sci., 30, 467-474.

Modisi, M. P., E. A. Atekwana, A. B. Kampunzu, and T. H. Ngwisanyi (2000), Rift kinematics during the incipient stages of continental extension: Evidence from the nascent Okavango rift basin, northwest Botswana, Geology, 102, 363-376.

Moore, A. E., and P. Larkin (2001), Drainage evolution in south-central Africa since the breakup of Gondwana, S. Afr. J. Geol., 104, 47-68.

Morelli, C. (1996), Modern standards for gravity surveys, Geophysics, 41, 1051.

Mosley-Bufford, K., E. A. Atekwana, M. G. Abdelsalam, E. Shemang, E. A. Atekwana, K. Mickus, M. Moidaki, M. P. Modisi, and L. Molwalefhe (2012), Geometry and faults tectonic activity of the Okavango Rift Zone, Botswana Evidence from magnetotelluric and electrical resistivity tomography imaging, J. Afr. Earth. Sci., 65, 61-71.

Muller, M. R., et al. (2009), Lithospheric structure and diamond prospectivity of the Rehoboth terrane and Western Kaapvaal craton, Southern Africa: Constraints from broadband magnetotellurics, Lithos, 112, 93-105.

Nair, K. S., S. G. Gao, K. H. Liu, and P. G. Silver (2006), Southern African crustal evolution and composition: Constraints from receiver function studies, J. Geophys. Res., 111, B02304, doi:10.1029/2005JB003802.

Nguuri, T. K., J. Gore, D. E. James, S. J. Webb, C. Wright, T. G. Zengeni, O. Gwavava, J. A. Snoke, and Kaapvaal Seismic Group (2001), Crustal structure beneath Southern Africa and its implications for the formation and evolution of the Kaapvaal and Zimbabwe cratons, Geophys. Res. Lett., 28, 2501-2504, doi:10.1029/2000GL012587.

Okubo, Y., R. J. Graf, R. O. Hansen, K. Ogowa, and H. Tsu (1985), Curie point depth of the island of Kyushu and surrounding areas, Japan, Geophysics, 50, 481-494.

Pollack, H. N., S. J. Hunter, and J. R. Johnson (1993), Heat flow from the Earth's interior: Analysis of the global data set, Rev. Geophys., 31 267-280, doi:10.1029/93RG01249.

Ravat, D., A. Pignatelli, I. Nicolosi, and M. Chiappini (2007), A study of spectral methods of estimating the depth to the bottom of magnetic sources from near-surface magnetic anomaly data, Geophys. J. Int., 169, 421-434.

Reeves, C. V. (1972), Rifting in the Kalahari?, Nature, 237, 95-96.

Ringrose, S., P. Huntsman-Mapila, A. B. Kampunzu, W. Matheson, W. Downey, B. Vink, C. Coetzee, and C. Vanderpost (2005), Sedimentological and geochemical evidence for palaeo-environmental change in the Makgadikgadi subbasin, in relation to the MOZ rift depression, Botswana, Palaeogeogr. Palaeoclimatol. Palaeoecol., 217, 265-287.

Ritter, O., U. Weckmann, T. Vietor, and V. Haak (2003), A magnetotelluric study of the Damara belt in Namibia regional scale conductivity anomalies, Phys. Earth Planet. Inter., 138, 71-90.

Roberts, E. M., N. J. Stevens, P. M. O'Conner, P. H. G. M. Dirks, M. D. Gottfried, W. C. Clyde, R. A. Armstrong, A. I. S. Kemp, and S. Hemming (2012), Initiation of the western branch of the East African Rift coeval with the eastern branch, Nat. Geosci., 5, $289-294$.

Ross, H. E., R. J. Blakely, and M. D. Zoback (2006), Testing the use of aeromagnetic data for the determination of Curie depth in California, Geophysics, 71, L51-L59. 
Rudnick, R. L., W. F. McDonough, and R. J. O'Connell (1998), Thermal structure, thickness and composition of continental lithosphere, Chem. Geol., 145, 395-411.

Saria, E., E. Calais, D. S. Stamps, D. Delvaux, and C. J. H. Hartnady (2014), Present-day kinematics of the East African Rift, J. Geophys. Res. Solid Earth, 119, 3584-3600, doi:10.1002/2013JB010901.

Schmeling, H. (2010), Dynamic models of continental rifting with melt generation, Tectonophysics, 480, 33-47.

Scholz, C. H., T. A. Koczynski, and D. G. Hutchins (1976), Evidence for incipient rifting in Southern Africa, Geophys. J. R. Astron. Soc., 44, 135-144.

Sebagenzi, M. N., G. Vasseur, and P. Louis (1993), First heat flow density determinations from Southeastern Zaire (Central Africa), J. Afr. Earth Sci., 16, 413-423.

Shemang, E. M., and L. N. Molwalefhe (2009), DC resistivity and seismic refraction survey across the SE margin of Lake Ngami, NW Botswana, Acta Geophys., 57, 728-742.

Shuey, R. T., D. Schellinger, A. Tripp, and L. Alley (1977), Curie depth determination from aeromagnetic spectra, Geophys. J. R. Astron. Soc., 50, 75-101.

Simiyu, S., and G. R. Keller (2001), An integrated geophysical analysis of the upper crust of the southern Kenya rift, Geophys. J. Int., 147, 543-561.

Singletary, S. J., R. E. Hanson, M. W. Martin, J. L. Crowley, S. A. Bowring, R. M. Key, L. V. Ramokate, B. B. Direng, and M. A. Krol (2003), Geochronology of basement rocks in the Kalahari Desert, Botswana, and implications for regional Proterozoic tectonics, Precambrian Res. $121,47-71$.

Spector, A., and F. Grant (1970), Statistical models for interpreting aeromagnetic data, Geophysics, 35, $293-302$.

Stacey, F., and S. Banerjee (1974), The Physical Principles of Rock Magnetism, 195 pp., Elsevier, Amsterdam.

Stamps, D. S., E. Calais, E. Saria, C. Hartnady, J.-M. Nocquet, C. J. Ebinger, and R. M. Fernandes (2008), A kinematic model for the East African Rift, Geophys. Res. Lett., 35, L05304, doi:10.1029/2007GL032781.

Tanaka, A., Y. Okubo, and O. Marsubayashi (1999), Curie point depth based on spectrum analysis of the magnetic anomaly data in East and Southeast Asia, Tectonophysics, 306, 461-470.

Tselentis, G. A., J. Drakopoulos, and K. Dimtriads (1988), A spectral approach to Moho depths estimation from gravity measurement in Epirus (NW Greece), J. Phys. Earth, 36, 255-266.

Wölbern, I., G. Rümpker, K. Link, and F. Sodoudi (2012), Melt infiltration of the lower lithosphere beneath the Tanzania craton and the Albertine rift inferred from S receiver functions, Geochem. Geophys. Geosyst., 13, Q0AK08, doi:10.1029/2011GC003955.

Wolski, P., and H. Savenije (2006), Dynamics of floodplain-island groundwater flow in the Okavango Delta, Botswana, J. Hydrol., 320, 283-301.

Yang, Z., and W. P. Chen (2010), Earthquakes along the East African Rift System: A multiscale, system-wide perspective, J. Geophys. Res., 115 B12309, doi:10.1029/2009JB006779. 